\title{
Human $\alpha 4 \beta 2$ Neuronal Nicotinic Acetylcholine Receptor in HEK 293 Cells: A Patch-Clamp Study
}

\author{
Bruno Buisson, ${ }^{1}$ Murali Gopalakrishnan, ${ }^{2}$ Stephen P. Arneric, ${ }^{2}$ James P. Sullivan, ${ }^{2}$ and Daniel Bertrand ${ }^{1}$ \\ ${ }^{1}$ Department of Physiology, Faculty of Medicine, University of Geneva, CH-1211 Geneva 4, Switzerland, and \\ ${ }^{2}$ Neuroscience Research, Abbott Laboratories, Abbott Park, Illinois 60064-3500
}

The cloning and expression of genes encoding for the human neuronal nicotinic acetylcholine receptors (nAChRs) has opened new possibilities for investigating their physiological and pharmacological properties. Cells (HEK 293) stably transfected with two of the major brain subunits, $\alpha 4$ and $\beta 2$, were characterized electrophysiologically using the patch-clamp technique. Fast application of the natural ligand ACh can evoke currents up to $3500 \mathrm{pA}$, with an apparent affinity $\left(\mathrm{EC}_{50}\right)$ of $3 \mu \mathrm{M}$ and a Hill coefficient of 1.2. The rank order of potency of four nAChR ligands to activate human $\alpha 4 \beta 2$ receptors is (-)-nicotine $>$ ACh $>(-)$-cytisine $>$ ABT-418. At saturating concentrations, the efficacy of these ligands is ABT-418 $\gg(-)$-nicotine $>$ ACh $\gg(-)$-cytisine $>$ GTS-21 (previously named DMXB). Coapplication of $1 \mu \mathrm{M}$ ACh with known nAChR inhibitors such as dihydro- $\beta$-erythroidine and methyllycaconitine re- versibly reduces the current evoked by the agonist with respective $I_{50}$ values of $80 \mathrm{~nm}$ and $1.5 \mu \mathrm{M}$. The current-voltage relationship of human $\alpha 4 \beta 2$ displays a strong rectification at positive potentials. Experiments of ionic substitutions suggest that human $\alpha 4 \beta 2 \mathrm{nAChRs}$ are permeable to sodium and potassium ions. In the "outside-out" configuration, ACh evokes unitary currents (main conductance $46 \mathrm{pS}$ ) characterized by a very fast rundown. Potentiation of the ACh-evoked currents is observed when the extracellular calcium concentration is increased from 0.2 to $2 \mathrm{~mm}$. In contrast, however, a reduction of the evoked currents is observed when calcium concentration is elevated above $2 \mathrm{~mm}$.

Key words: human; $\alpha 4 \beta 2$; neuronal; nicotinic; acetylcholine; receptor
Neuronal nicotinic acetylcholine receptors (nAChRs) constitute a family of cationic ligand-gated channels (Bertrand and Changeux, 1995; Galzi and Changeux, 1995) closely related to but distinct from the muscle nAChR. To date, eight neuronal $\alpha(\alpha 2-\alpha 9)$ and three neuronal $\beta(\beta 2-\beta 4)$ subunits have been cloned in chick and rodents (Lindstrom, 1995; McGehee and Role, 1995) and also identified in humans (Anand and Lindstrom, 1990; DoucetteStamm et al., 1993; Peng et al., 1994; Monteggia et al., 1995; for review, see Lindstrom, 1996). Furthermore, it was even shown that some neuronal subunits are transiently expressed in chick striated muscles during embryonic development (Corriveau et al., 1995)

The $\alpha 4$ and $\beta 2$ subunits represent the most abundant nAChR subunits in chick and rat brains (Whiting et al., 1987; Schoepfer et al., 1988; Wada et al., 1989; Flores et al., 1992), and $\alpha 4$ mRNA is widely detected throughout the human cerebral cortex (Wevers et al., 1994). A good correlation exists between the high-affinity $(-)$-nicotine binding sites and the rodent brain regions expressing the $\alpha 4$ and $\beta 2$ subunits (Clarke et al., 1985; Deutch et al., 1987; Swanson et al., 1987; Marks et al., 1992). Moreover, $\beta 2$-containing nAChRs constitute the high-affinity binding sites for (-)-nicotine, as demonstrated in the $\beta 2$ gene knock-out experiment in which $(-)$-nicotine binding to brain slices is fully abolished in transgenic

Received Aug. 2, 1996; revised Sept. 16, 1996; accepted Sept. 30, 1996.

This research was supported by grants from the Swiss National Science Foundation (D.B.), the Office Federal de l'Education et des Sciences (D.B.), and the Human Frontier Science Program (D.B.). B.B. is the recipient of a research fellowship from the J. Thorn Foundation. We thank Sonia Bertrand for comments and suggestions during the preparation of this manuscript.

Correspondence should be addressed to Daniel Bertrand, Department of Physiology, University of Geneva, 1 Rue M. Servet, CH-1211 Geneva 4, Switzerland.

Copyright (C) 1996 Society for Neuroscience $0270-6474 / 96 / 167880-12 \$ 05.00 / 0$ mice (Picciotto et al., 1995). Thus, characterization of the physiological and pharmacological properties of the human $\alpha 4 \beta 2$ nAChR may be pertinent to a more complete understanding of the physiological effect of (-)-nicotine in human brain (Kellar et al., 1989; Marks et al., 1992; Sanderson et al., 1993; Lukas, 1995).

Alterations in the level/activity of brain nAChRs have been implicated in different neuropathologies such as Tourette's syndrome (Silver and Sandberg, 1993), Parkinson's disease (Baron, 1986; Janson et al., 1994), and even schizophrenia (Goff et al., 1992). In the brain of Alzheimer's patients, the nAChR density is markedly reduced compared with that of age-matched controls (Whitehouse et al., 1986; Aubert et al., 1992). Moreover, the high-affinity binding of (-)-nicotine to brain regions that are believed to express mainly $\alpha 4 \beta 2 \mathrm{nAChRs}$ is extensively reduced in Alzheimer's patients (Perry et al., 1995). The attention deficits observed in those patients have been attenuated by subcutaneous injection of (-)-nicotine (Jones et al., 1992), suggesting that (-)-nicotine, or other nAChR ligands (Decker et al., 1994a; Arendash et al., 1995; Arneric et al., 1995), could be used for the treatment of Alzheimer's disease. In addition, several studies have demonstrated beneficial effects of $(-)$-nicotine on cognitive functions (Levin, 1992; Warburton, 1992; Picciotto et al., 1995).

Recently, a missense mutation in the human $\alpha 4$ neuronal $\mathrm{nAChR}$ subunit has been associated with the autosomal dominant nocturnal frontal lobe epilepsy (Steinlein et al., 1995). Other genetic investigations have linked the $\alpha 4 \mathrm{nAChR}$ subunit with another form of epilepsy: the benign familial neonatal convulsions (Beck et al., 1994; Schubert et al., 1994).

The human $\alpha 4$ and $\beta 2$ cDNAs have recently been cloned (Monteggia et al., 1995) and stably transfected into HEK 293 cells (K177 clone; Sullivan et al., 1995; Gopalakrishnan et al., 1996). 
Herein we describe the electrophysiological properties of the human $\alpha 4 \beta 2 \mathrm{nAChR}$ using the whole-cell and single-channel patch-clamp techniques (Hamill et al., 1981).

\section{MATERIALS AND METHODS}

Cell transfection and culture. The cDNAs encoding the human $\alpha 4$ and $\beta 2$ subunits were cloned into the BstXI site of the pRcCMV vector (Invitrogen, San Diego, CA) containing the genes conferring hygromycin or neomycin resistance, respectively (Gopalakrishnan et al., 1996). After transfection by lipofectamine (Gopalakrishnan et al., 1995), HEK 293 cells (K177 clone) were grown in DMEM with $10 \%$ fetal bovine serum plus the mixed antibiotic antimycotic at $37^{\circ} \mathrm{C}$ in an atmosphere of $95 \%$ air $/ 5 \% \mathrm{CO}_{2}$ at saturating humidity. Cells were cultured continuously in the presence of geneticin $(250 \mu \mathrm{g} / \mathrm{ml})$ and hygromycin $(100 \mu \mathrm{g} / \mathrm{ml})$ to avoid outgrowth of cells that do not express genes conferring the corresponding resistances and thereby also the $\alpha 4$ and $\beta 2$ subunits. All cell culture products were from Life Technologies (Basel, Switzerland). Three to six days before electrophysiological recordings, the cells were incubated with trypsin for 3 min, mechanically dissociated, and seeded in 35-mm-diameter petri dishes (Nunc, Basel, Switzerland) at a density of $\sim 300$ cells/dish. The same batch of K177 cells was cultured during a 15 month period without resampling from the frozen stock. No significant variation in the percentage of responsive cells or maximum ACh-evoked currents was observed during this time period. This suggests that the level of nAChR expression remains unchanged even after many cell cycles.

Electrophysiological recordings. The experiments were performed at room temperature. The standard bath solution for whole-cell recordings had the following composition (in mM): $120 \mathrm{NaCl}, 5 \mathrm{KCl}, 2 \mathrm{MgCl}_{2}, 2$ $\mathrm{CaCl}_{2}, 25$ glucose, 10 Hepes; and $1 \mu \mathrm{M}$ atropine (for blocking endogenous muscarinic receptors), $\mathrm{pH} 7.4$ with $\mathrm{NaOH}$. Borosilicate electrodes $(2-8$ $\mathrm{M} \Omega$ ) used for both whole-cell and "outside-out" recordings were filled with (in mM): $120 \mathrm{KF}, 10 \mathrm{KCl}, 5 \mathrm{NaCl}, 2 \mathrm{MgCl}_{2}, 20$ BAPTA, 10 Hepes, $\mathrm{pH} 7.4$ with $\mathrm{KOH}$. For ionic substitution experiments in the whole-cell configuration, $\mathrm{MgCl}_{2}$ was removed from the extracellular solution. The other modifications of the bath composition are given in the figure legends. The intracellular solution was modified as followed: $\mathrm{NaCl}$ and $\mathrm{MgCl}_{2}$ were omitted. Outside-out recordings were performed with an extracellular solution containing no $\mathrm{MgCl}_{2}$ and with Sylgard-coated electrodes to minimize the capacitance of the electrodes; the pipette was filled with the standard intracellular solution containing $2 \mathrm{mM} \mathrm{MgCl}_{2}$. Currents, recorded on isolated cells using an Axopatch 200A amplifier (Axon Instruments, Foster City, CA), were filtered on line at $1-2 \mathrm{kHz}$, digitized at $2-5 \mathrm{kHz}$, and stored on a personal computer equipped with an analog-to-digital converter (ATMIO-16D, National Instrument, Austin, Texas) and the DATAC package (Bertrand and Bader, 1986). Data were analyzed on a Macintosh Performa 5200 using the MacDATAC program. Fast superfusion of the cells was performed with a custom-made multibarrel (eight tubings) puffer, which allows drug application in the millisecond range (Puchacz et al., 1994; Gopalakrishnan et al., 1995; Bertrand et al., 1997), and fast exchange between the different solutions can be evaluated by ionic substitution during a steady response to a low ACh concentration (Fig. 1). All chemicals were from Sigma or Fluka

\section{$1 \mu \mathrm{M} \mathrm{ACh}$}

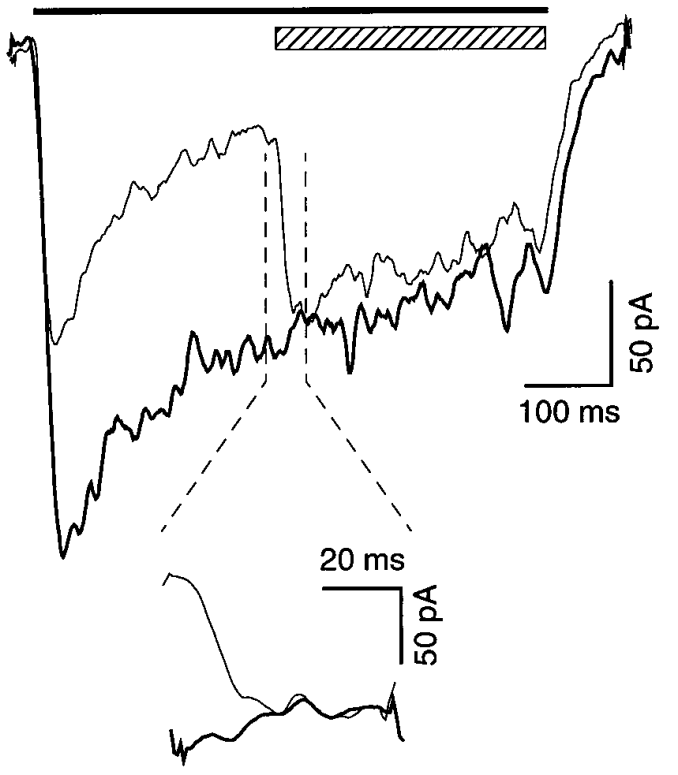

Figure 1. Fast drug application using a multibarrel puffer. The time course for a complete solution exchange on a cell was determined by performing a sodium jump during a steady application of a low ACh concentration. The first "control" current (bold trace) was recorded in a standard medium containing $130 \mathrm{~mm} \mathrm{NaCl}$. A second current (light trace) was elicited by applying $\mathrm{ACh}$ in a solution containing $65 \mathrm{~mm} \mathrm{NaCl}+130$ $\mathrm{mM}$ mannitol. Then the solution was switched for the standard medium (rectangle with diagonal lines), and the current was returned to the level of the control trace. The inset (bottom) presents with an expanded time scale the current rise time induced by the sodium jump. Complete solution exchange is performed within $20 \mathrm{msec}$.

(Buchs, Switzerland). Unless specified, the holding potential was -100 $\mathrm{mV}$. All values are given as mean $\pm \mathrm{SEM}$.

\section{RESULTS}

\section{Pharmacological properties of the human $\alpha 4 \beta 2 \mathrm{nAChR}$}

$\mathrm{ACh}$, the endogenous ligand for human nAChRs, elicited currents in transfected cells at concentrations $\geq 0.1 \mu \mathrm{M}$ (Fig. $2 A$ ). Maximal current recorded was up to $-3500 \mathrm{pA}$, whereas the mean current amplitude of 20 cells challenged with $1 \mu \mathrm{M} \mathrm{ACh}$ was $-824 \pm 112 \mathrm{pA}$ (holding potential, $-100 \mathrm{mV}$ ), demon-
A

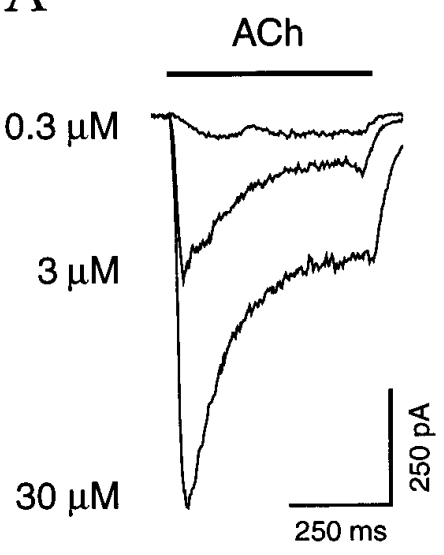

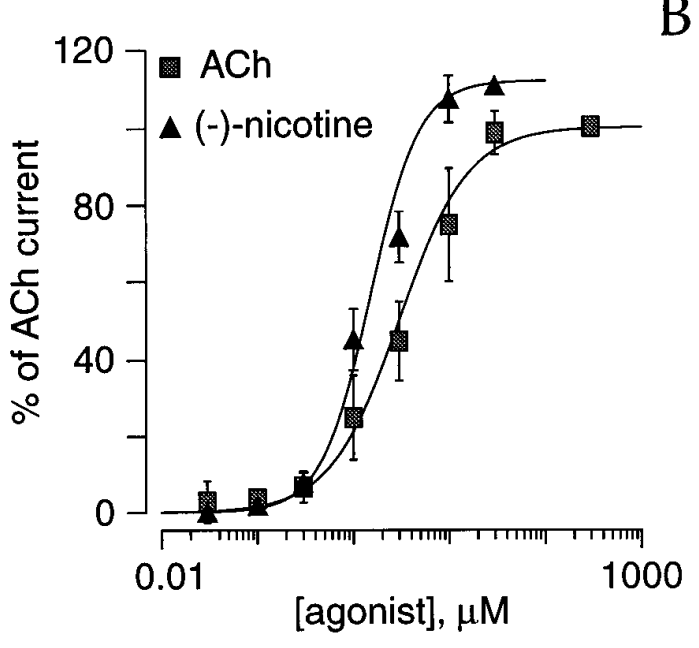

B

Figure 2. Sensitivity of human $\alpha 4 \beta 2 \mathrm{nAChRs}$ toward $\mathrm{ACh}$ and (-)-nicotine. $A$, Currents evoked by increasing concentrations of $\mathrm{ACh}$ (pulse of $500 \mathrm{msec}$ ) in a cell held at $-100 \mathrm{mV} . B$, Concentration-response curves for (-)-nicotine and $\mathrm{ACh}$. Dose-response relationships were fitted with the empirical Hill equation $y=1 /(1+$ $\left.\left(\left(\mathrm{EC}_{50} /[\text { agonist }]\right)^{n}\right)\right)$. Half-effective concentrations $\left(\mathrm{EC}_{50}\right)$ were then determined: $1.6 \mu \mathrm{M}(n=$ $1.3)$ for $(-)$-nicotine (5 cells) and $3 \mu \mathrm{M}(n=1.2)$ for ACh (19 cells). 
A

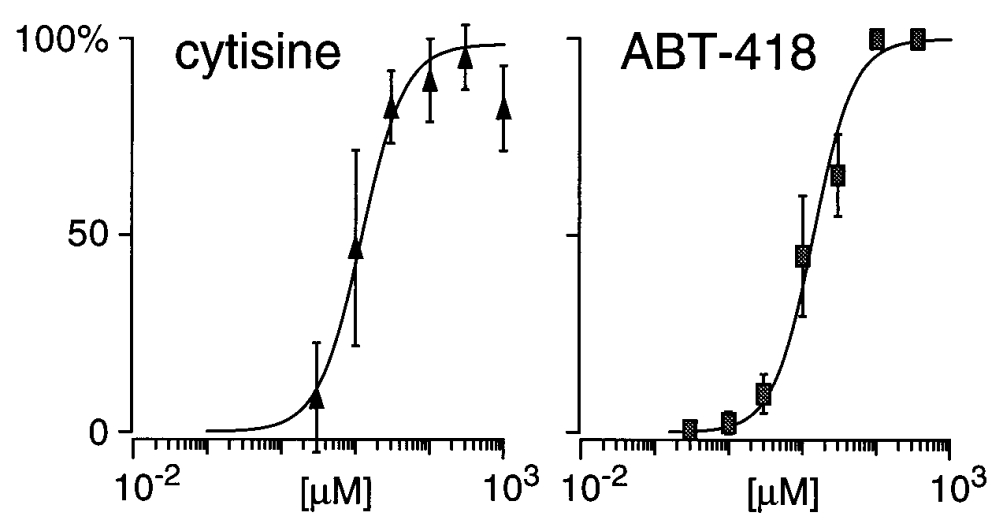

C

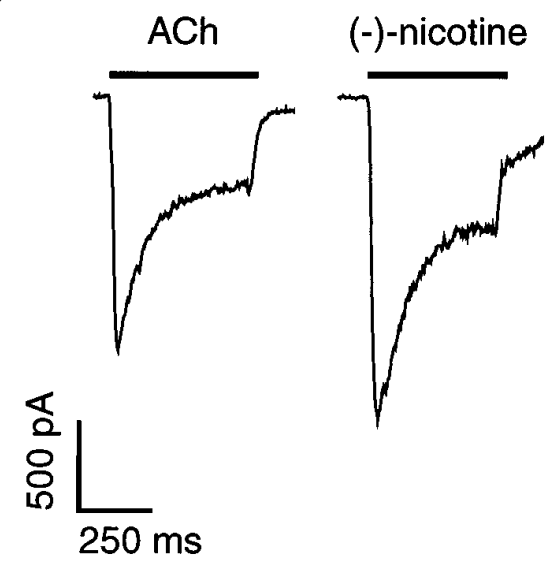

ABT-418

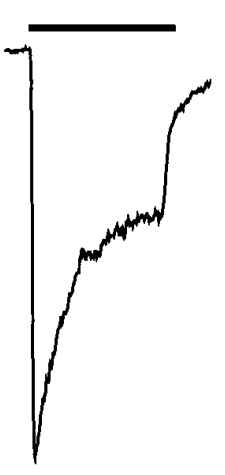

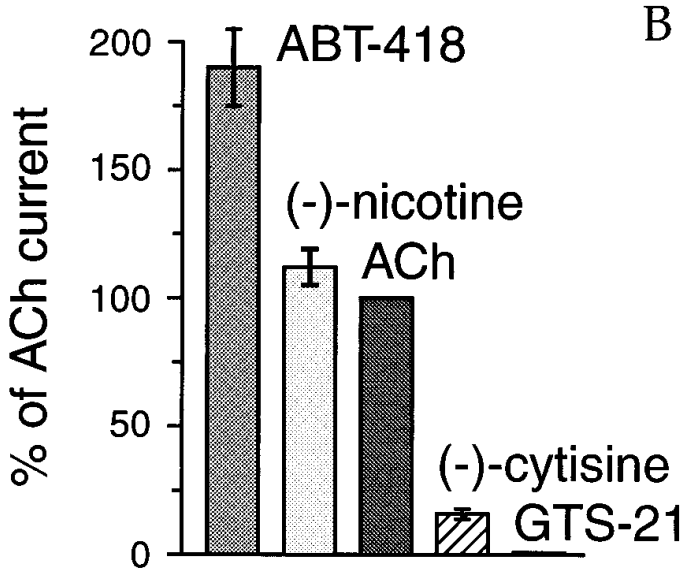

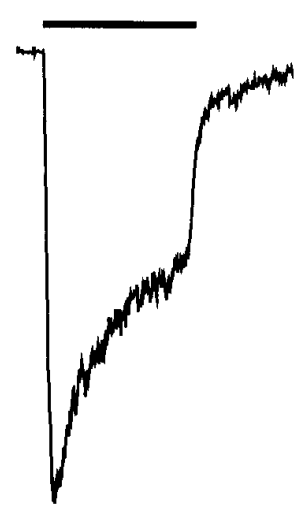

$\mathrm{ACh}$
GTS-21

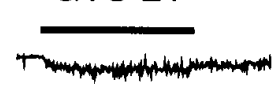

$\mathrm{D}$

Figure 3. Agonists are characterized by different affinities and efficacies for human $\alpha 4 \beta 2 \mathrm{nAChRs.} A$, Transfected HEK 293 cells were challenged with six to seven concentrations of each agonist (ranging from 0.3 to $300 \mu \mathrm{M}$ ). Data were then normalized against the largest evoked current and plotted on a semi-logarithm scale. Mean values were fitted with the empirical Hill equation (see Fig. 2 legend) giving $\mathrm{EC}_{50}$ values $(\mu \mathrm{M})$ and Hill coefficient $(n)$ : (-)-cytisine (11.6, 1.5; 7 cells) and ABT-418 (13.9, 1.3; 13 cells). $B$, The efficacy of the agonist was determined at saturating concentration (100 $\mu \mathrm{M}$ each but $300 \mu \mathrm{M}$ for ABT-418), with a holding potential of $-100 \mathrm{mV}$. For accurate determination, the following protocol of sequential drug application (500 msec each, every $4.5 \mathrm{sec}$ ) was used: alternate applications of the agonists to be tested and ACh. A first set of measures was performed with ACh, (-)-nicotine, and ABT-418 (7 cells) and another one with ACh, $(-)$-cytisine and GTS-21 (7 cells). Currents were normalized as in $A$. ABT-418 evoked $190 \pm 15 \%$ of saturating ACh current, whereas (-)-nicotine produced $112 \pm 7 \%$. In contrast, (-)-cytisine and GTS-21 can elicit only $16 \pm 2 \%$ and $6 \pm$ $2 \%$ of the ACh-evoked current, respectively. A typical example of the currents evoked on one cell by $100 \mu \mathrm{M}$ ACh, (-)-nicotine and $100 \mu \mathrm{M}$ ABT-418 is presented in $C$. A very weak current evoked by $100 \mu \mathrm{M}$ GTS- 21 is compared with the $100 \mu \mathrm{M}$ ACh current for another cell in $D$.

strating the very substantial expression of $\alpha 4$ and $\beta 2$ subunits in this cell line. Of 312 impaled cells, only $1.6 \%$ (five cells) did not present detectable currents. Data collected over a broad range of ACh concentrations $(0.03-300 \mu \mathrm{M})$ were normalized and fitted with the empirical Hill equation, allowing the determination of an apparent half-effective concentration $\left(\mathrm{EC}_{50}\right)$ of 3 $\mu \mathrm{M}$ and a Hill coefficient of 1.2 (Fig. 2B). Identical protocols were performed for three other agonists: (-)-nicotine, (-)cytisine, and the recently characterized nAChR ligand ABT418 (Arneric et al., 1994; Decker et al., 1994b). (-)-Nicotine was the most potent of the ligands investigated, with an $\mathrm{EC}_{50}$ of $1.6 \mu \mathrm{M}$ (Fig. 2B), whereas (-)-cytisine and ABT-418 (with $\mathrm{EC}_{50}$ values of 11.6 and $13.9 \mu \mathrm{M}$, respectively) were less potent than either (-)-nicotine or ACh (Fig. 3A). The efficacy of these agonists, and for the anabaseine-derived compound GTS-21 (previously named DMXB; Hunter et al., 1994) to activate $\alpha 4 \beta 2 \mathrm{nAChRs}$, was determined at a saturating concentration (100 $\mu \mathrm{M}$ each but $300 \mu \mathrm{M}$ for ABT-418; Fig. 3B-D). ABT-418 was the most efficacious of the agonists, eliciting $190 \pm 15 \%$ of the ACh-evoked current (Fig. 3B,C). (-)-Nicotine was slightly more efficacious than ACh, but (-)-cytisine and GTS-21 behaved as very weak agonists at this nAChR (Fig. 3B,D). To further characterize the pharmacological profile of human $\alpha 4 \beta 2$ nAChRs, the effects of two well known competitive inhibitors of $\mathrm{nAChRs}$, dihydro- $\beta$-erythroidine $(\mathrm{DH} \beta \mathrm{E})$ (Mulle and Changeux, 1990; Whiting et al., 1991) and methyllycaconitine (MLA) (Wonnacot et al., 1993), were investigated. MLA is a potent antagonist (in the nanomolar range) of the $\alpha 7$ homomeric nAChRs (Gopalakrishnan et al., 1995; Palma et al., 1996). Less than micromolar concentrations of $\mathrm{DH} \beta \mathrm{E}$ completely blocked the ACh-evoked currents. Complete reversibility of inhibition was obtained within $10 \mathrm{sec}$ (three cells; data not shown). The following inhibition protocol was then performed for $\mathrm{DH} \beta \mathrm{E}$ : every $10 \mathrm{sec}$ a $1 \mu \mathrm{M}$ ACh-pulse was delivered for $1200 \mathrm{msec}$, and a $\mathrm{DH} \beta \mathrm{E}$ jump was applied during the last $800 \mathrm{msec}$ (Fig. 4, inset). The percentage of DH $\beta E$-induced inhibition has been plotted as a function of the logarithm of the antagonist concentrations, and the data were fitted with an 


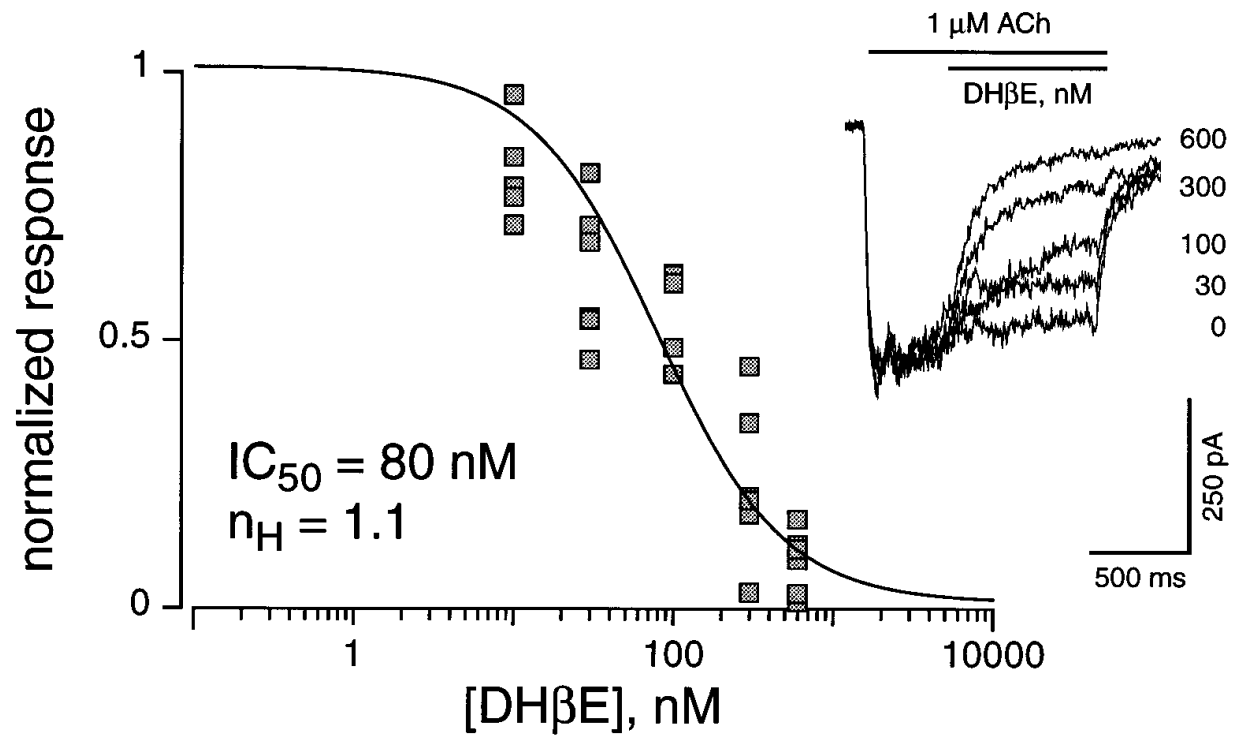

Figure 4. Dihydro- $\beta$-erythroidine $(D H \beta E)$ antagonizes the effect of $\mathrm{ACh}$ on the human $\alpha 4 \beta 2$ nAChRs. Every $10 \mathrm{sec}$, a $1200 \mathrm{msec}$ pulse was delivered alternately with $1 \mu \mathrm{M} \mathrm{ACh}$ alone or with $1 \mu \mathrm{M} \mathrm{ACh}$ and increasing concentrations of $\mathrm{DH} \beta \mathrm{E}(0-600 \mathrm{nM})$ in coapplication for the last $800 \mathrm{msec}$ (see an example of the recorded currents on one cell in the inset). The full block of the ACh-evoked current by $600 \mathrm{~nm} \mathrm{DH} \beta \mathrm{E}$ was totally reversed within $10 \mathrm{sec}$ (not shown; 3 cells). The inhibitory effect of $\mathrm{DH} \beta \mathrm{E}$ was measured at the end of the pulse of co-application (steady-state current) and normalized toward the value of the plateau amplitude of the preceding AChevoked current. Values were plotted against the concentrations of $\mathrm{DH} \beta \mathrm{E}$ (on a logarithm scale) and fitted with the empirical Hill equation: $y=1 /\left(1+\left(\left([\mathrm{DH} \beta \mathrm{E}] / \mathrm{IC}_{50}\right)^{n}\right)\right)$, where $\mathrm{IC}_{50}$ and $n$ represent the half-inhibitory concentration and the Hill coefficient, respectively. The calculated $\mathrm{IC}_{50}$ value is $80 \mathrm{~nm}$ with an $n$ value of $1.1(n=6)$.

empirical Hill equation (Fig. 4). The apparent half-inhibitory concentration $\left(\mathrm{IC}_{50}\right)$ for $\mathrm{DH} \beta \mathrm{E}$ was $80 \mathrm{nM}$.

Using the same methodological approach, MLA inhibited the functional activity of human $\alpha 4 \beta 2 \mathrm{nAChRs}$ with an apparent $\mathrm{IC}_{50}$ of $1.5 \mu \mathrm{M}$ (Fig. 5), which is not significantly different from the value previously measured for the chick $\alpha 4 \beta 2 \mathrm{nAChR}$ (Drasdo et al., 1992). No detectable block of human $\alpha 4 \beta 2$ nAChRs was observed for concentrations of MLA below $0.5 \mu \mathrm{M}$. By analogy to observations made on other neuronal nAChRs (Palma et al., 1996; Harvey and Luetje, 1996), it is supposed that both $\mathrm{DH} \beta \mathrm{E}$ and MLA act on the human $\alpha 4 \beta 2$ as competitive inhibitors. Confirmation of this mode of action, however, has not been examined further.

As previously reported for chick (Bertrand et al., 1990) and for rat (Charnet et al., 1992) $\alpha 4 \beta 2$ nAChRs, the open-channel blocker hexamethonium (at concentrations higher than $10 \mu \mathrm{M}$ ) strongly inhibited the ACh-evoked current when co-applied with ACh $(n=8$; data not shown).

\section{Ionic permeability and voltage dependence of the human $\alpha \mathbf{4} \beta 2$ nAChR}

Determination of the human $\alpha 4 \beta 2$ nAChR current-voltage relationship was accomplished either with voltage step or voltage ramp protocols. Recordings of the ACh-evoked currents obtained over a broad voltage range are illustrated in Figure 6. In every cell tested, ACh failed to evoke detectable current for potentials above $0 \mathrm{mV}$. Figure $6 B$ illustrates the mean amplitude currents obtained from three cells.

The strong rectification of these channels and the absence of significant outward currents at positive potentials prevented any reliable measurements of the ACh-evoked current reversal potential. This precluded clear cut determination of the ionic selectivity of this nAChR. Because intracellular $\mathrm{Mg}^{2+}$ has been shown to participate in the rectification mechanisms in different $\mathrm{nAChR}$ preparations (Mathie et al., 1990; Ifune and Steinbach, 1992; Sands and Barish, 1992; Albuquerque et al., 1995; Forster and Bertrand, 1995; Bonfante-Cabarcas et al., 1996), experiments were designed to reduce the intracellular free $\mathrm{Mg}^{2+}$ concentration; however, rectification was not modified by either removal of $\mathrm{Mg}^{2+}$ from the intracellular medium or addition into the pipette of $5 \mathrm{~mm}$ CDTA, a specific chelator agent that was successfully used to overcome rectification of the homomeric $\alpha 7 \mathrm{nAChR}$ (Forster and Bertrand, 1995).

Substitution of the extracellular sodium by mannitol (Bertrand et al., 1993) almost completely abolished the ACh-evoked current (Fig.
A

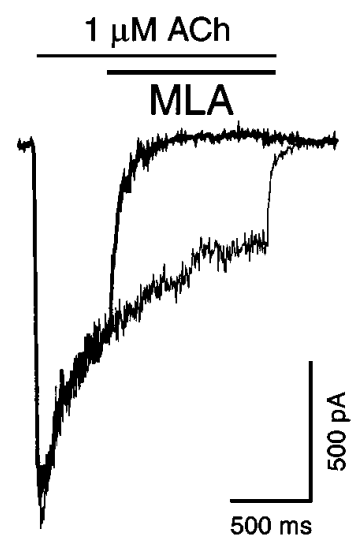

B

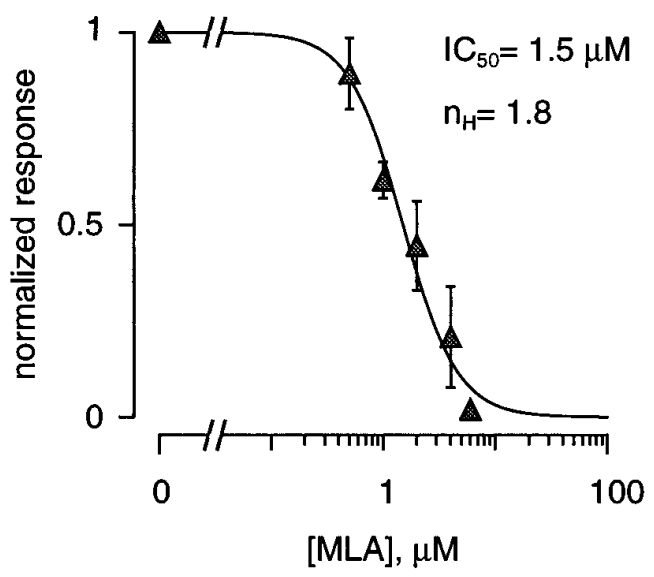

Figure 5. Methyllycaconitine (MLA) inhibits the AChevoked current at the human $\alpha 4 \beta 2 \mathrm{nAChR}$ in the micromolar range. A protocol identical to that used in Figure 4 was applied for the determination of the antagonistic properties of MLA. Traces corresponding to a $1 \mu \mathrm{M}$ AChevoked current before and after a $6 \mu \mathrm{M}$ MLA jump are presented in $A$. Normalized values were plotted as a function of the concentration of MLA represented on a logarithm scale $(B)$ and fitted with the empirical Hill equation (see Fig. 4 legend). An $\mathrm{IC}_{50}$ of $1.5 \mu \mathrm{M}(n=1.8)$ was calculated from the mean \pm SEM values collected on four cells. 
A
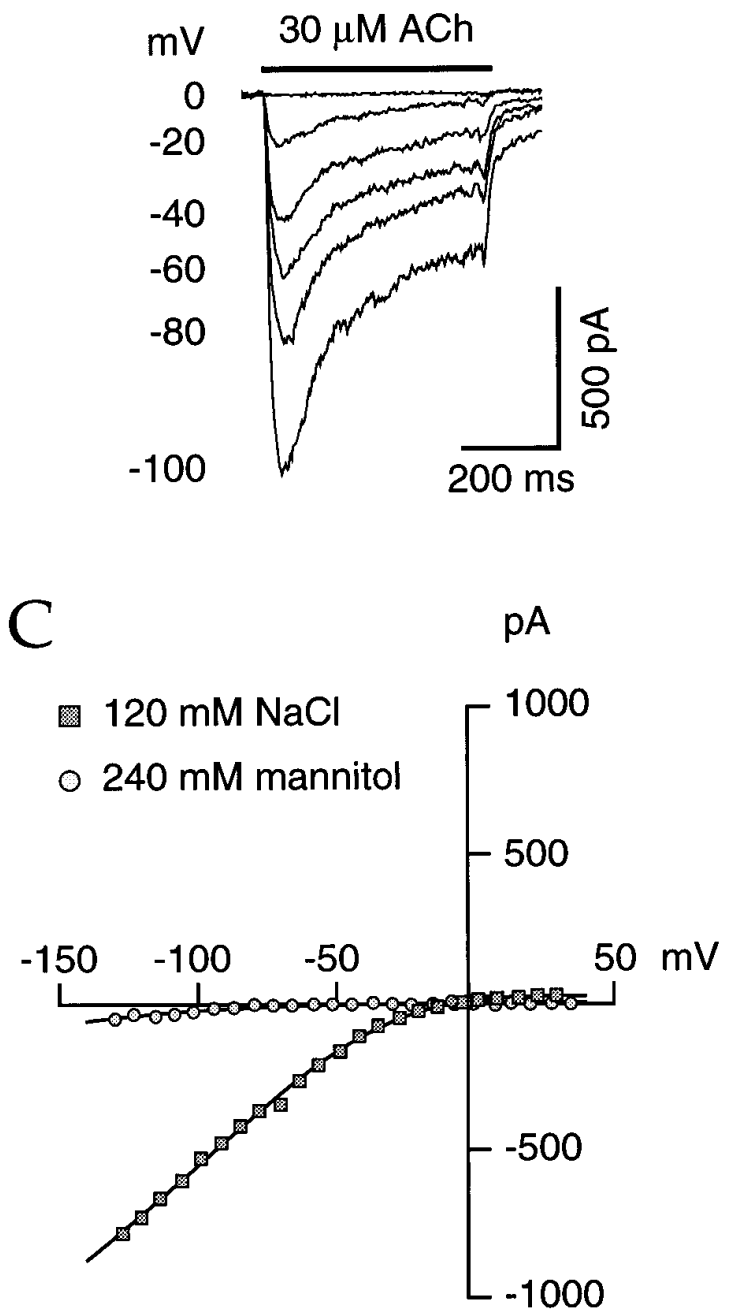

B

\section{holding potential $(\mathrm{mV})$}

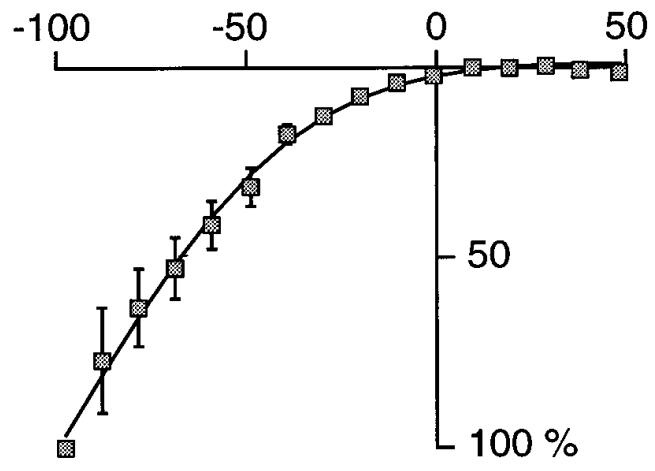

$\mathrm{D}$

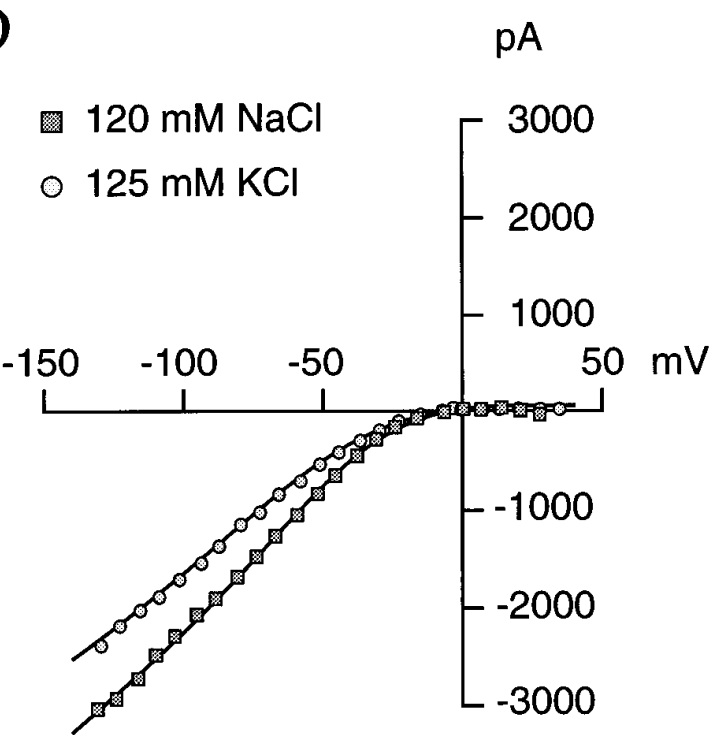

Figure 6. Human $\alpha 4 \beta 2 \mathrm{nAChRs}$ demonstrate strong rectification at positive potentials and are highly permeable to $\mathrm{Na}^{+}$and $\mathrm{K}^{+}$ions. ACh-evoked currents were recorded for holding potentials ranging from -100 to $40 \mathrm{mV}$ with $10 \mathrm{mV}$ steps every $4.5 \mathrm{sec}$ in the standard extracellular solution; ACh was delivered $400 \mathrm{msec}$ after the new set of the voltage. $A$ presents typical currents; for clarity, traces were omitted for all odd values. $B$, Currents were normalized against values measured at $-100 \mathrm{mV}$. Mean values of three cells were plotted as a function of the holding potentials. Data were fit (solid line) by the following equation: $y=\left(V-E_{\mathrm{r}}\right) /\left(1+\exp \left(\alpha \times\left(V-V_{1 / 2}\right)\right)\right)$, where $V$ is the holding voltage, $E_{\mathrm{r}}$ is the current reversal potential, $V_{1 / 2}$ is the potential for the half-current amplitude, and $\alpha$ is the slope factor. This formula corresponds to the product of the driving force and a Boltzmann equation. Optimal fit was obtained with $V_{1 / 2}=-83.1 \mathrm{mV}$ and $\alpha=0.043$. For the determination of the selectivity against cations, experiments using voltage ramps were performed with different extracellular solutions $(C, D)$. The membrane was held at $-10 \mathrm{mV}$, and a first ramp (from 40 to $-140 \mathrm{mV}$ in $400 \mathrm{msec}$ ) was applied in saline medium (without ACh) for the determination of the leak current. Four seconds later, $1 \mu \mathrm{M}$ ACh was delivered for $800 \mathrm{msec}$, and the voltage ramp was applied again $200 \mathrm{msec}$ after the beginning of ACh delivery. The leak current has been subtracted to the ACh-evoked current for all the data presented. For clarity, experimental current values are plotted every 20 points, corresponding to approximately one measurement every $7.5 \mathrm{mV}$. When extracellular $\mathrm{Na}^{+}$chloride $(\mathrm{NaCl})$ was replaced by mannitol, the quantity of ACh-evoked current was very weak $(\mathrm{C})$, indicating a high permeability of the human $\alpha 4 \beta 2 \mathrm{nAChR}$ for $\mathrm{Na}^{+}$ions (but see text). This $\mathrm{nAChR}$ is also highly permeable to potassium ions. When extracellular Na ${ }^{+}$chloride is replaced by an equimolar concentration of potassium chloride, the amplitude of the ACh-evoked current is still large $(D)$; note that the reversal potential for potassium ions switched from approximately $-80 \mathrm{mV}$ to $0 \mathrm{mV}$ during this ionic substitution.

$6 C)$, whereas replacement of the extracellular sodium chloride by potassium chloride (Fig. 6D) or by sodium methanesulfonate (data not shown) induced no significant reduction of the ACh-evoked current. Taken together, these data indicate that as with other known nAChRs, these channels should be permeable to cations and that under physiological conditions, sodium ions are likely the major carrier ions flowing through the open $\mathrm{nAChR}$ channels.

\section{Single-channel recordings}

All outside-out patches were pulled in a magnesium-free solution, whereas pipette medium contained $2 \mathrm{~mm} \mathrm{MgCl}_{2}$. Single-channel activities were regularly observed on withdrawal of the electrode from the whole-cell configuration $(n=75)$. This activity was observed in response to $\mathrm{ACh}$ and readily blocked by coapplication of $\mathrm{DH} \beta \mathrm{E}(600 \mathrm{~nm} ; n=3)$, thereby demonstrating that such elementary currents corresponded to multiple openings of human $\alpha 4 \beta 2$ nAChRs (Fig. 7A). In all patches recorded, a predominant current amplitude was always observable at different holding potentials (Fig. $7 B, D$ ). Plots of the main single current amplitude as a function of the holding voltage (Fig. $7 C, D$ ) could be fitted with a straight line yielding a conductance of $46 \mathrm{pS}$ and 
a reversal potential of $\sim-7 \mathrm{mV}$. Single-channel properties of neuronal $\alpha 4 \beta 2$ nAChRs from chick and/or rat have been investigated previously (Ballivet et al., 1988; Papke et al., 1989; Cooper et al., 1991; Charnet et al., 1992). Only one conductance state of $20 \mathrm{pS}$ has been described for the chick $\alpha 4 \beta 2 \mathrm{nAChR}$ (Ballivet et al., 1988; Cooper et al., 1991), whereas two or three (12, 22, and $34 \mathrm{pS}$ ) conductances were observed for the rat $\alpha 4 \beta 2 \mathrm{nAChR}$ (Papke et al., 1989; Charnet et al., 1992). Single-channel recordings on M10 cells expressing the chick $\alpha 4 \beta 2 \mathrm{nAChR}$ also revealed two conductance states (18 and 30 pS; Pereira et al., 1994). Recordings of the single-channel properties of the human $\alpha 4 \beta 2$ showed a predominant conductance of $\sim 46 \mathrm{pS}$. Occasionally, however, multiple levels were observed in some recordings, suggesting that channels can either undergo a rapid flickering or might display multiple conductances. Importantly, a rundown comparable to that reported originally for the chick and rat $\alpha 4 \beta 2$ nAChR (Ballivet et al., 1988; Charnet et al., 1992; Pereira et al., 1994) was observed in every patch analyzed (see below). Obviously, however, given the short time of recordings, we cannot eliminate the possibility of other conducting states occurring at very low frequency (Papke et al., 1989; Charnet et al., 1992). Many investigations have indicated that second transmembrane segments (TM-2) of the neuronal nAChRs subunits form the channel wall and determine the receptor ionic selectivity (for review, see Bertrand et al., 1993; Karlin and Akabas, 1995). Alignment of the TM-2 amino acid sequences of chick, rat, and human reveals an excellent conservation of this segment among the $\alpha 4$ and $\beta 2$ subunits (Le Novère and Changeux, 1995; Lindstrom, 1996). Thus, differences in the main single-channel conductances observed between chick, rat, and human $\alpha 4 \beta 2$ nAChRs are not readily attributable to differences of the TM-2 segments. In addition, it is unlikely that differences in single-channel conductances result from the expression method of these subunits with either mammalian cell lines or Xenopus oocytes. Differences in channel conductance, however, could result from recording conditions, and namely the ionic strength used.

The single-channel currents did not rectify when patches were held at positive potentials (Fig. 7C,D), as observed previously in other outside-out recordings of nAChRs (Ballivet et al., 1988; Mathie et al., 1990; Neuhaus and Cachelin, 1990; Mulle et al., 1992). The lack of rectification is further reinforced when recordings are made from outside-out patches containing a large number of channels (Fig. 7E). Compared with the whole-cell recordings data (Fig. 6), currents recorded in these patches showed no rectification at positive potentials. The linear relationship observed between current and voltage indicates that conductance of these channels follows Ohm's law.

As shown in Figure 8, ACh-evoked single channels in outsideout patches are characterized by a very fast rundown that can be fit by a single exponential process whose time constant is $\sim 47 \mathrm{sec}$. A similar rundown was observed in many patches. Its time course was independent of the ACh concentration or the application protocol and could not be prevented by adjunction of BAPTA, MgATP, or GTP in the patch pipette.

\section{Effects of extracellular $\mathrm{Ca}^{2+}$ on the human $\alpha 4 \beta 2$ nAChR}

It is known that extracellular $\mathrm{Ca}^{2+}$ potentiates, in a dosedependent manner, the agonist-evoked whole-cell currents of native or reconstituted neuronal nAChRs (Mulle et al., 1992; Vernino et al., 1992; Eiselé et al., 1993) and is therefore considered a positive allosteric modulator (Léna and Changeux, 1993).
To characterize the putative influence of extracellular $\mathrm{Ca}^{2+}$ on human $\alpha 4 \beta 2$ nAChRs, several experimental paradigms were designed. Determination of the current-voltage relationships in three external calcium concentrations $(0.2,2,20 \mathrm{~mm})$ revealed that the amplitude of the evoked currents was maximal at $2 \mathrm{~mm}$ (Fig. 9A). Furthermore, these calcium effects were independent of the polarity of the ramp protocol (data not shown). Identical results were observed when the cell membrane was held at -100 $\mathrm{mV}$ (Fig. 9B). Although expected for low calcium concentrations, the reduction of the amplitude of the ACh-evoked currents observed for higher external calcium content suggests that several mechanisms might play a role in the modulation of the human $\alpha 4 \beta 2$ nAChR. To evaluate the kinetics and mechanism underlying the calcium effects, calcium jump experiments on steady-state ACh-evoked currents were performed (Fig. 9C). Currents recorded under these conditions revealed that fast and fully reversible inhibition of the nAChR-elicited current occurred.

To characterize the effect of high extracellular $\mathrm{Ca}^{2+}$ concentrations on the single-channel currents at several potentials, protocols allowing investigation of the current over a broad voltage range in different calcium concentrations were designed. Data obtained from a single patch recorded successively in 20 and $2 \mathrm{mM}$ of extracellular $\mathrm{Ca}^{2+}$ is presented in Figure $9 D$. The amount of current recorded in $2 \mathrm{mM} \mathrm{Ca}^{2+}$ was much larger (at all potentials) than equivalent currents measured in $20 \mathrm{mM} \mathrm{Ca}^{2+}$. The main unitary amplitude (as illustrated in Fig. $9 E$ ) was measured for three patches in both $\mathrm{Ca}^{2+}$ concentrations and plotted as a function of the holding potential (Fig. 9F). The conductance decreased from 46 to $28 \mathrm{pS}$ when calcium was raised from 2 to 20 mM. Reversal potentials estimated by linear interpolation yielded intercepts ranging between -9 and $-6 \mathrm{mV}$ in $2 \mathrm{mM} \mathrm{Ca}^{2+}$ and between -8 and $-5 \mathrm{mV}$ in $20 \mathrm{mM} \mathrm{Ca}^{2+}$.

\section{DISCUSSION}

\section{Functional expression of the human $\alpha \mathbf{4} \beta 2 \mathrm{nAChR}$}

Reverse transcription-PCR analysis of total RNA isolated from the transfected (k177 clone), but not untransfected, cell line indicated the appropriate translation of mRNAs corresponding to $\alpha 4$ and $\beta 2$ cDNAs (Gopalakrishnan et al., 1996). Moreover, ACh (1 mM) elicited no detectable current in wild-type HEK 293 cells, confirming the absence of functional nAChRs in the membranes of untransfected cells (Gopalakrishnan et al., 1995). Identical results were obtained in the absence of atropine. Thus, the AChevoked currents observed in K177 cells can be attributed only to the functional expression of the $\alpha 4$ and $\beta 2$ subunits.

\section{Pharmacological profile of the human $\alpha \mathbf{4} \beta 2 \mathrm{nAChR}$}

Using a fast perfusion method (Puchacz et al., 1994; Gopalakrishnan et al., 1995; Bertrand et al., 1997) (Fig. 1), we have established that human $\alpha 4 \beta 2 \mathrm{nAChRs}$ display the following sensitivity: (-)nicotine $>\mathrm{ACh}>(-)$-cytisine $>\mathrm{ABT}-418$. The small difference in apparent affinities between $\mathrm{ACh}$ and (-)-nicotine, however, remains to be confirmed by measurements on a larger sample of cells and different experimental protocols. When expressed in Xenopus laevis oocytes, human $\alpha 4 \beta 2 \mathrm{nAChRs}$ present an equivalent sensitivity and Hill coefficient for ACh (Sonia Bertrand, personal communication). Although ABT-418 is 10 -fold less potent than (-)-nicotine in activating human $\alpha 4 \beta 2 \mathrm{nAChRs}$, it is significantly more efficacious. Given the fast application method used in these experiments, and the relatively slow responses of the $\alpha 4 \beta 2 \mathrm{nAChRs}$, the differences in the potency of ABT-418, (-)nicotine, and ACh seem not to be attributable to partial desensi- 
A

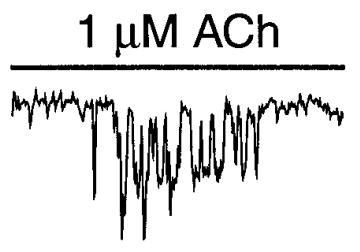

$1 \mu \mathrm{M}$ ACh
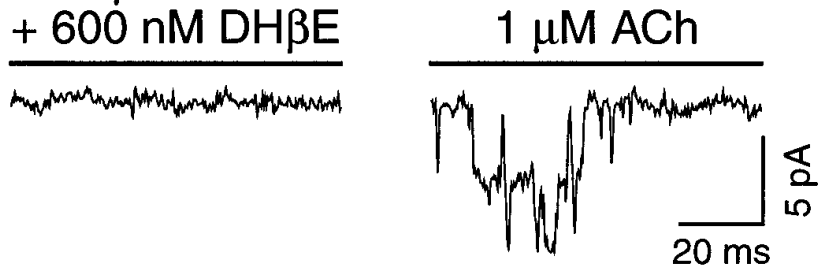

B
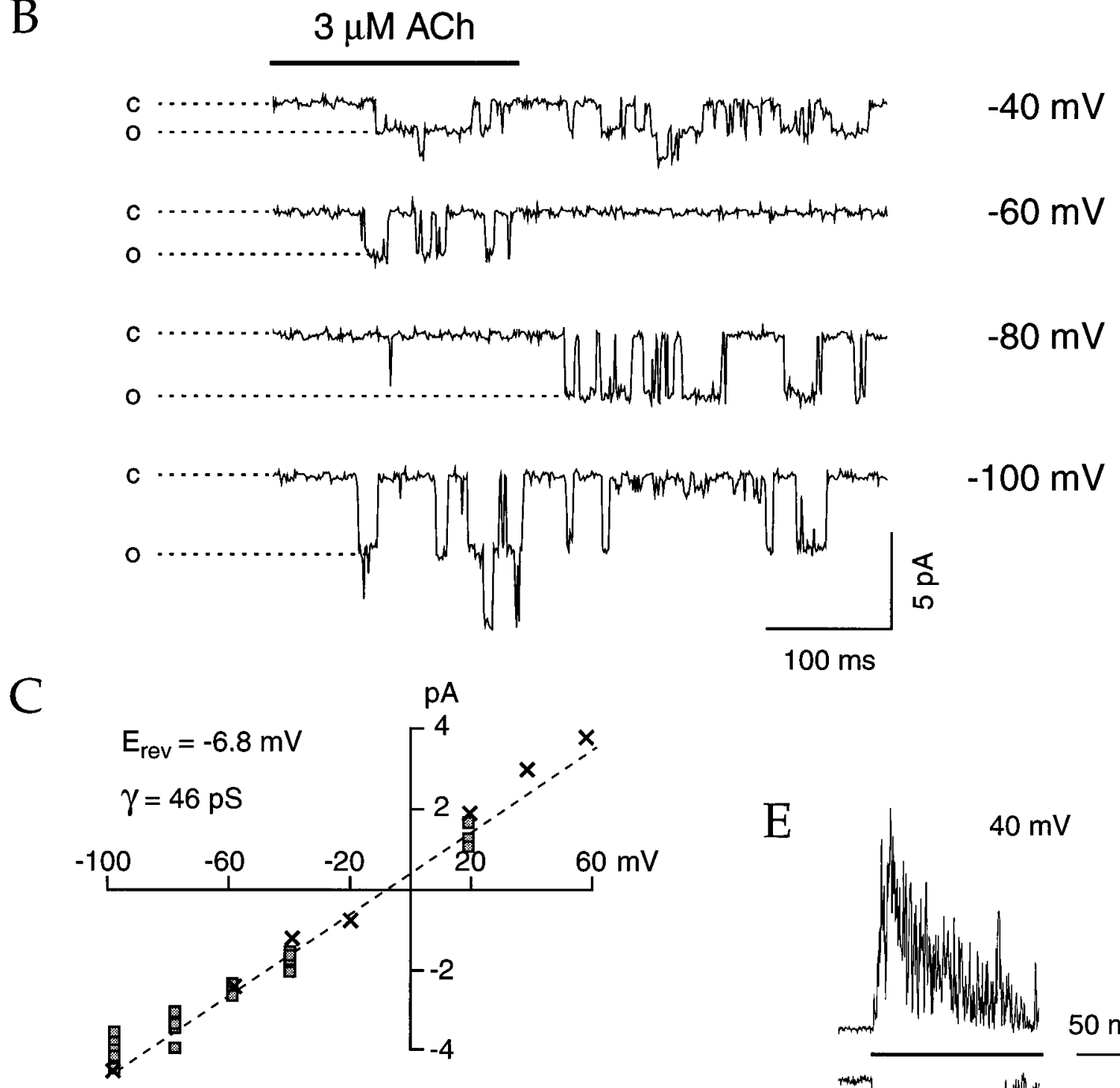

$\mathrm{D}$

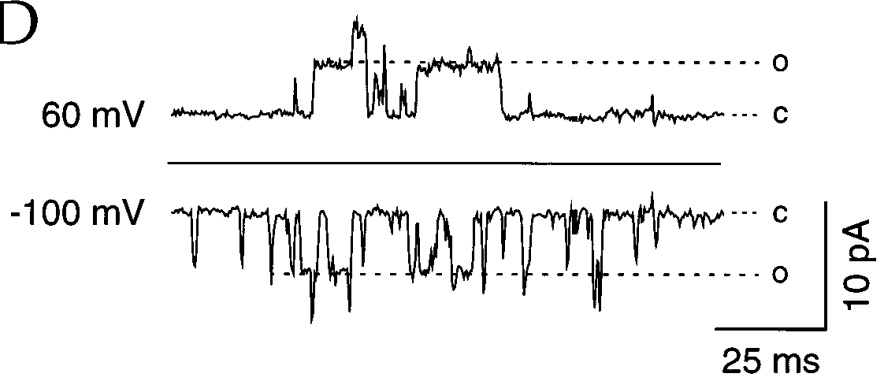

$\mathrm{E}$

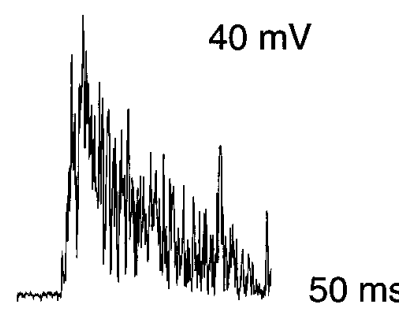

Figure 7. In the outside-out configuration, ACh-evoked single channels are blocked by DH $\beta \mathrm{E}$, display a main conductance of $46 \mathrm{pS}$, and do not rectify at positive holding voltages. Intracellular solution (see Materials and Methods) contained $2 \mathrm{mM} \mathrm{MgCl}_{2}$. A high concentration of DH $\beta \mathrm{E}(600 \mathrm{nM}$; IC 50 $80 \mathrm{nM}$ ) completely inhibited the ACh-evoked single channels $(A)$, demonstrating that these single-channel currents resulted from nAChR activation by ACh $(n=3)$. Figure legend continues. 
A

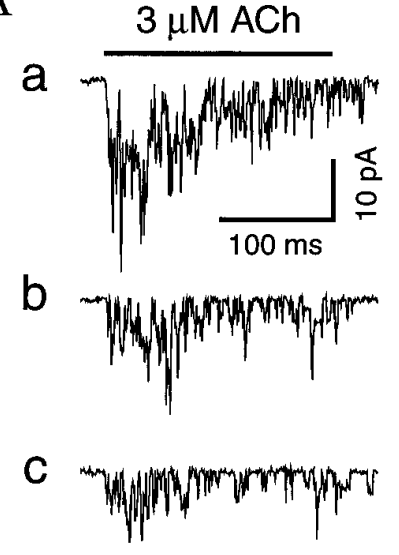

B

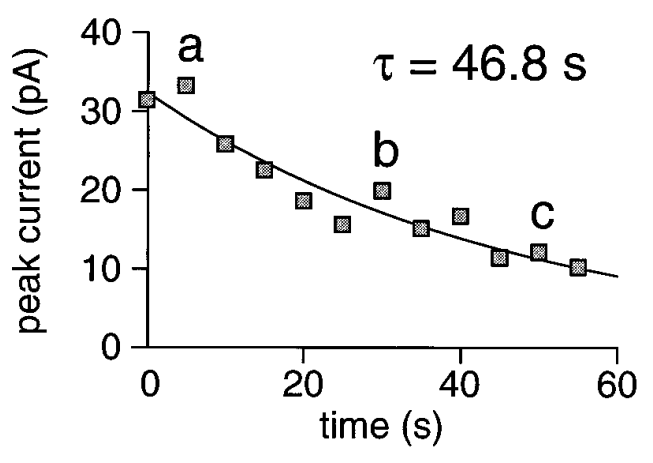

Figure 8. ACh-elicited single channels present fast run-down properties. In the outside-out configuration, the activity of the channels disappeared within minutes. The current recorded on a typical patch is presented in $A$, and the corresponding peak current amplitudes were plotted as a function of time in $B$. The current-time values were fitted with a single exponential function giving a time constant of $46.8 \mathrm{sec}$. tization of the receptor to compounds like (-)-nicotine or ACh. Thus it is possible that ABT-418 preferentially stabilizes the opened (and conducting) state(s) of the nAChRs and thereby evokes larger currents. It is noteworthy that ABT-418 behaves as a partial agonist on the human homomeric $\alpha 7 \mathrm{nAChR}$ expressed in HEK 293 cells where detectable currents were observed only for concentrations of ABT-418 above $300 \mu \mathrm{M}$ (B. Buisson, J. P. Sullivan, and D. Bertrand, unpublished observations). These data illustrate the "pharmacological signature" displayed by different nAChRs subtypes within the same species.

In contrast to ABT-418, the anabaseine-derivative GTS-21, which is currently in clinical trial for the treatment of Alzheimer's disease, behaves as a very weak agonist of the $\alpha 4 \beta 2 \mathrm{nAChR}$. The amount of current elicited by GTS-21 was only $6 \%$ of the ACh-evoked currents (Fig. 3B,D). These data are in good agreement with those obtained previously with the rat $\alpha 4 \beta 2 \mathrm{nAChRs}$ reconstituted in Xenopus oocyte (Hunter et al., 1994; De Fiebre et al., 1995). The observation that this anabaseine-derived compound acts as a stronger agonist of the rat $\alpha 7$ homo-oligomeric nAChR (De Fiebre et al., 1995) further reinforces the concept of a pharmacological signature that is specific to each neuronal nAChR.

Homomeric $\alpha 7 \mathrm{nAChRs}$ are blocked by MLA at nanomolar concentrations (Wonnacott et al., 1993; Gopalakrishnan et al., 1995; Palma et al., 1996), whereas the human $\alpha 4 \beta 2$ subtype is fully inhibited at concentrations above $10 \mu \mathrm{M}$ (see Fig. 5).

Analysis of the potency of another nAChR antagonist such as $\mathrm{DH} \beta \mathrm{E}$ reveals that an $\mathrm{IC}_{50}$ of $0.08 \mu \mathrm{M}$ at the human $\alpha 4 \beta 2 \mathrm{nAChRs}$ compares rather well with the values obtained for the avian $\alpha 4 \beta 2$ nAChRs (Pereira et al., 1994) as well as the value determined for "type II" currents of cultured rat hippocampal neurons (Alkondon and Albuquerque, 1993). It was proposed that these currents result mainly from the activation of receptors comprising $\alpha 4$ and $\beta 2$ subunits and that they were completely inhibited by infusion of $10 \mathrm{nM}$ $\mathrm{DH} \beta \mathrm{E}$ (Alkondon and Albuquerque, 1993). Similar preliminary results have been described with human nAChRs expressed in $\mathrm{Xe}$ nopus oocytes: $\mathrm{DH} \beta \mathrm{E}$ inhibits much more selectively $\alpha 4-$ and $\alpha 2$ than $\alpha 3$-containing receptors (Chavez-Noriega et al., 1995; Wong et al., 1995). Further investigations should confirm whether $\mathrm{DH} \beta \mathrm{E}$ could be used as a relative selective inhibitor of $\alpha 4$ - (and $\alpha 2$-) versus $\alpha 3$-containing nAChRs. Other experiments are needed, however, to assess the possible contribution of $\beta$ subunits in the $\mathrm{DH} \beta \mathrm{E}$ sensitivity (Duvoisin et al., 1989; Luetje et al., 1990; Hussy et al., 1994; Cachelin and Rust, 1995; Corringer et al., 1995; Harvey and Luetje, 1996).

\section{Comparison of electrophysiology with ${ }^{86} \mathbf{R b}^{+}$efflux}

In previous characterization of the human $\alpha 4 \beta 2$ nAChR (Gopalakrishnan et al., 1996), it was shown using rubidium $\left({ }^{86} \mathrm{Rb}^{+}\right)$ efflux that this receptor is about $10 \times$ more sensitive to (-)nicotine than $\mathrm{ACh}$. Comparison of these data with characterizations of the $\alpha 4 \beta 2$ nAChRs (Bertrand et al., 1990; McGehee and Role, 1995; for review, see Lindstrom, 1996) from other species suggested that human receptor might display a specific pharmacological profile. In contrast, however, data obtained with patchclamp recordings (see above) are in good agreement with results from other studies (for review, see McGehee and Role, 1995). Thus, it seems that the initial discrepancies are attributable to the differences in techniques with flux measurements, on the one hand, and with electrophysiological recordings, on the other hand. The ${ }^{86} \mathrm{Rb}^{+}$efflux technique requires long incubations (in the minute range) in the presence of the agonist, whereas millisecond exposures are typically used in electrophysiological recordings. Thus, the apparent discrepancies observed between these two experimental approaches might be attributed to inevitable desensitization of the receptor occurring during the ion flux protocol.

\section{Rectification properties of the human $\alpha \mathbf{4} \beta 2$ nAChR}

Current-voltage relationships recorded in the whole-cell configuration either by voltage steps or by voltage ramps displayed a

\footnotetext{
An outside-out patch stimulated by ACh at different holding potential clearly showed the voltage dependence of the ACh-evoked current and the predominant conductance observed in many other records $(n=46)(B)$. This patch contained at least two channels, but their activity disappeared before we were able to record at positive potentials. The closed $(c)$ and opened $(o)$ states are indicated by the dotted lines. In contrast to the whole-cell configuration experiments, the current-voltage relationship for the main conductance of the human $\alpha 4 \beta 2 \mathrm{nAChR}$ is linear and shows no rectification $(C)$. The amplitude values collected for six outside-out patches were fitted (straight line) with the current equation $i=\gamma \times\left(E-E_{\mathrm{r}}\right)$, where $\gamma$ is the conductance, $E_{\mathrm{r}}$ is the reversal potential, and $E$ is the holding potential. The human $\alpha 4 \beta 2 \mathrm{nAChR}$ displays a main conductance of $46 \mathrm{pS}$ with a reversal potential of $-6.8 \mathrm{mV}$, confirming the high permeability of this ligand-gated channel for $\mathrm{Na}^{+}$and $\mathrm{K}^{+}$ions. $X$ corresponds to single-channel amplitudes measured on a patch lasting long enough to allow examination of single-channel apertures at positive voltages. $D$, Current traces recorded at -100 and $60 \mathrm{mV}$. $E$, Loss of rectification in the outside-out configuration was also observed on large membrane patches containing numerous receptor proteins. Traces were recorded at -60 and $40 \mathrm{mV}$, respectively. In $D-E$, currents were elicited by $1 \mu \mathrm{M}$ ACh (horizontal bar) applications.
} 
A

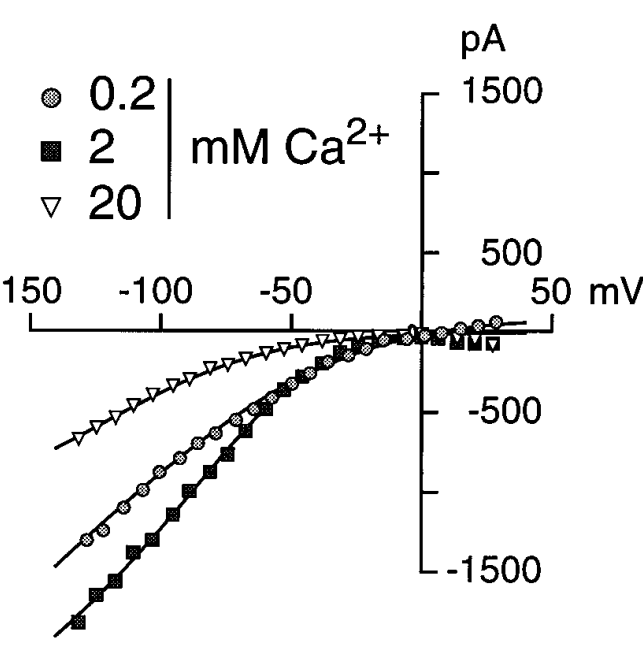

B

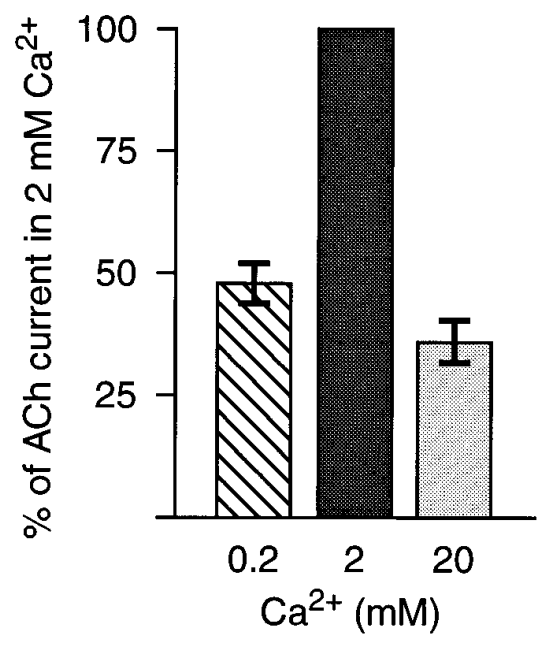

C

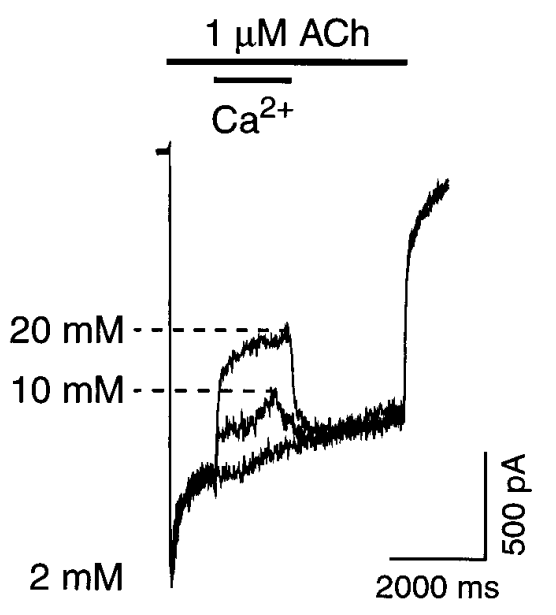

D

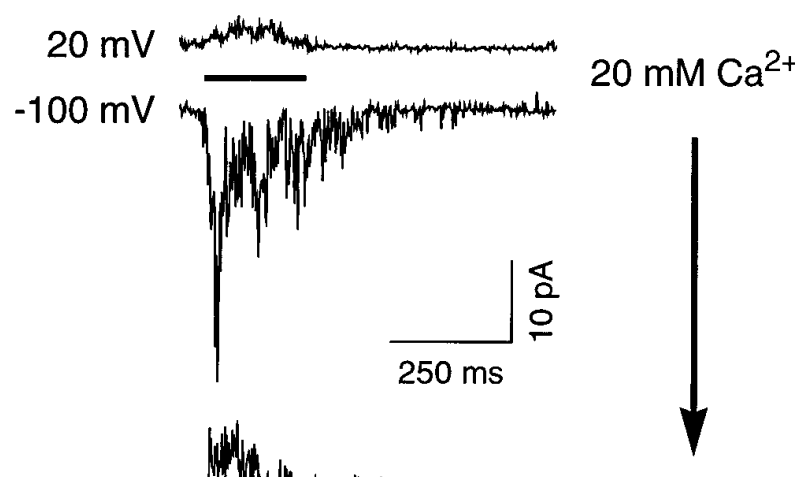

E
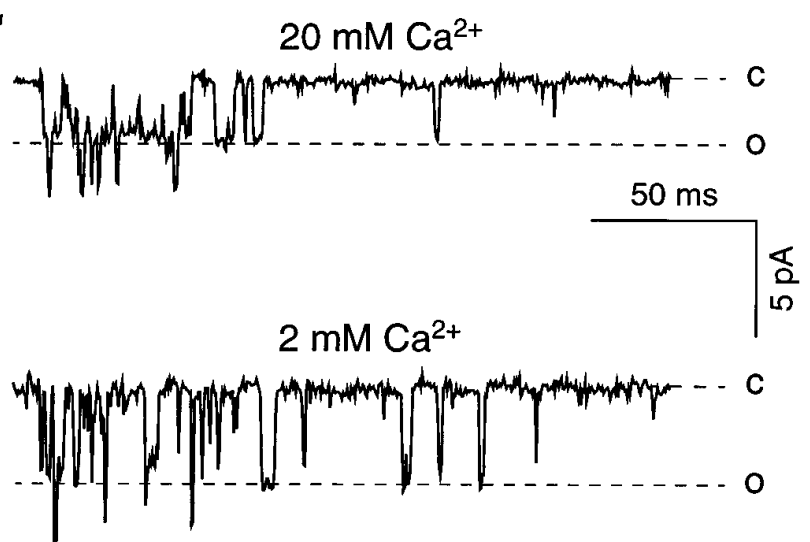

F

pA

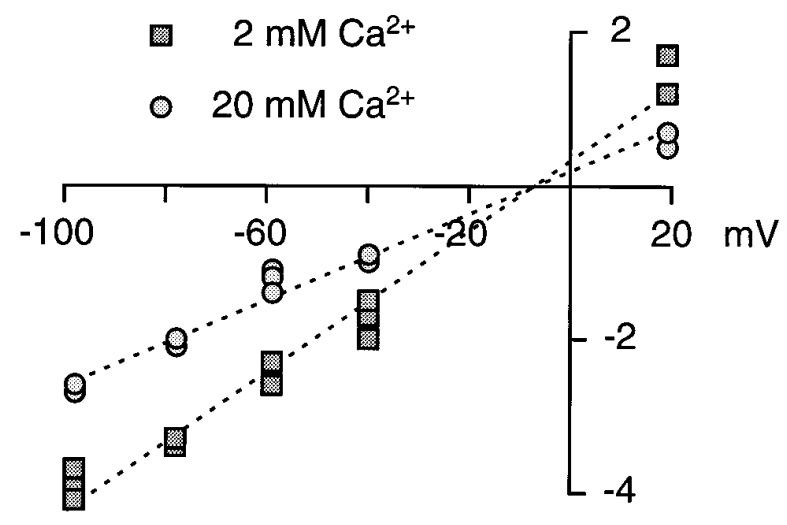


strong outward rectification (Fig. 6A,B). Additionally, rectification was not modified either by removal of intracellular $\mathrm{Mg}^{2+}$ or combined with the addition of the $\mathrm{Mg}^{2+}$ chelator CDTA in the pipette. In contrast, and independent of the presence of intracellular $\mathrm{Mg}^{2+}$, rectification was absent from the single-channel recordings obtained in the outside-out configuration (Fig. 8D,E; and see below). A similar observation was reported previously for the rat medial habenular neuron nAChRs (Mulle et al., 1992), a region known to express mRNAs encoding for $\alpha 4$ and $\beta 2 \mathrm{nAChR}$ subunits (Mulle et al., 1991). The mechanisms underlying neuronal $\mathrm{nAChR}$ rectification have been analyzed more extensively in rat sympathetic ganglion neurons (Mathie et al., 1990) and in the PC12 cell line (Neuhaus and Cachelin, 1990; Ifune and Steinbach, 1991, 1992, 1993; Sands and Barish, 1992). Data obtained by Mathie et al. (1990) allowed them to conclude that in native heteromeric nAChRs, rectification cannot be attributed to the effect of intracellular $\mathrm{Mg}^{2+}$ alone. In contrast, however, rectification of both native and reconstituted $\alpha 7$ subunits can be abolished when $\mathrm{Mg}^{2+}$ is removed from the intracellular medium (Albuquerque et al., 1995; Forster and Bertrand, 1995; Bonfante-Cabarcas et al., 1996). These observations indicate that the mechanisms underlying rectification in $\alpha 4 \beta 2$ or $\alpha 7$ are distinct. Given the fast rundown and thus the absence of possible analysis of the opening probability or the burst duration, however, differences between nAChRs recorded in whole-cell or outside-out configurations cannot be ruled out in the present study. Thus, in agreement with Mathie et al. (1990), our data suggest that a factor other than $\mathrm{Mg}^{2+}$ must be invoked to explain the rectification of the human $\alpha 4 \beta 2 \mathrm{nAChR}$ observed in the whole-cell configuration. Recent findings indicate that intracellular polyamines determine the rectification of the potassium channel inward rectifier (Ficker et al., 1994; Lopatin et al., 1994; Falker et al., 1995) or of the kainate/ AMPA subtypes of the glutamate receptors (Bowie and Mayer, 1995). Further experiments will be needed to investigate the possible effects of these compounds on native nAChRs.

\section{High external $\mathrm{Ca}^{2+}$ inhibits human $\alpha 4 \beta 2 \mathrm{nAChR}$ whole-cell currents}

Vernino et al. (1992) and Mulle et al. (1992) have shown that extracellular $\mathrm{Ca}^{2+}$ is a positive modulator of rat neuronal nAChRs (Léna and Changeux, 1993). In those studies, $\mathrm{Ca}^{2+}$ increased the whole-cell current amplitude while at the same time reducing the single-channel conductances, and these effects are more pronounced at lower agonist concentrations. In the present study, we observed that whole-cell currents are decreased both in low external $\mathrm{Ca}^{2+}$ (i.e., $\left[\mathrm{Ca}^{2+}\right]<2 \mathrm{mM}$ ) and in high external $\mathrm{Ca}^{2+}$ (i.e., $\left[\mathrm{Ca}^{2+}\right]>2 \mathrm{~mm}$ ), with an optimal amplitude at $\sim 2 \mathrm{~mm}$. This suggests that the positive $\mathrm{Ca}^{2+}$-induced modulation is observed for low $\mathrm{Ca}^{2+}$ concentrations (0.2-2 mM) but might be absent, or overcome by another mechanism, at higher concentrations. The inhibitory effect of high external $\mathrm{Ca}^{2+}$ differentiates the human $\alpha 4 \beta 2 \mathrm{nAChR}$ from the other characterized neuronal nAChRs (Mulle et al., 1992; Vernino et al., 1992). We observe a significant reduction of the single-channel conductance in a high calcium concentration (see Fig. 9), a result that is in full accordance with previous findings (Mulle et al., 1992; Vernino et al., 1992). The single-channel amplitude decrease could be interpreted as a screening mechanism for divalent cations (Imoto et al., 1988; Decker and Dani, 1990; Cooper et al., 1991). It is of value to note that a short pulse of $20 \mathrm{~mm} \mathrm{Ca}^{2+}$ decreases the ACh-evoked current by $\sim 40 \%$ (Fig. $9 C$ ). Because this decrease is comparable to the reduction of the single-channel conductance $(39 \%)$, it is probable that calcium inhibition results mainly from a screening charge effect. At present, however, involvement of other mechanisms cannot be ruled out.

In the absence of definitive assessment of the native neuronal $\mathrm{nAChR}$ stoichiometry and determination of the complete subunit family, one might postulate that an additional $\alpha$ (Conroy et al., 1992) or $\beta$ subunit may be necessary for the reconstitution of the native human $\alpha 4 \beta 2$ containing nAChRs. Although this crucial question remains open at present, it is clear that the results described herein will facilitate studies probing the functional differences in $\alpha 4 \beta 2$ nAChRs that might be observed in human pathologies.

\section{REFERENCES}

Albuquerque EX, Pereira EF, Castro NG, Alkondon M, Reinhardt S, Schroder H, Maelicke A (1995) Nicotinic receptor function in the mammalian central nervous system. Ann NY Acad Sci 757:48-72.

Alkondon M, Albuquerque EX (1993) Diversity of nicotinic acetylcholine receptors in rat hippocampal neurons. I. Pharmacological and functional evidence for distinct structural subtypes. J Pharmacol Exp Ther 265:1455-1473.

Anand R, Lindstrom J (1990) Nucleotide sequence of the human nicotinic acetylcholine receptor $\beta 2$ subunit gene. Nucleic Acids Res 18:4272. Arendash GW, Sengstock GJ, Sandberg PR, Kem WR (1995) Improved learning and memory in aged rats with chronic administration of the nicotinic receptor agonist GTS-21. Brain Res 674:252-259.

Arneric SP, Sullivan JP, Briggs CA, Donnelly RD, Anderson DJ, Raszkiewicz JL, Hughes ML, Cadman ED, Adams P, Garvey DS, Wasicak JT, Williams M (1994) (S)-3-methyl-5-(1-methyl-2-pyrrolidinyl) isox-

\footnotetext{
Figure 9. High external $\mathrm{Ca}^{2+}$ decreases both whole-cell and single-channel currents of the human $\alpha 4 \beta 2 \mathrm{nAChR}$. Voltage ramps (see Fig. 6 legend) were performed in external solutions containing (in $\mathrm{mM}$ ): $130 \mathrm{NaCl}, 10 \mathrm{HEPES}, 20$ glucose, and varying concentrations of $\mathrm{CaCl}_{2}$. When external calcium is increased from 0 to $2 \mathrm{mM}$, a significant potentiation of the ACh-evoked current for holding potentials less than $-50 \mathrm{mV}$ was observed; however, high calcium concentrations ( 10 or $20 \mathrm{~mm}$ ) strongly inhibit the ACh-evoked current for holding potentials below $0 \mathrm{mV}$. $A$ displays typical current-voltage relationships recorded on a single cell in three different calcium concentrations $(1 \mu \mathrm{M} \mathrm{ACh})$. For clarity, the current value is plotted once every 20 recorded points, corresponding to approximately one measurement every $7.5 \mathrm{mV}$. Continuous lines were computed using the same equation as for Figure 6 . The calcium effects have been quantified by measuring for each cell the amplitude of the plateau currents (elicited by $1 \mu \mathrm{M} \mathrm{ACh}, 500 \mathrm{msec}$ ) recorded in three different calcium concentrations at $-100 \mathrm{mV}(B)$. The mean amplitude of the currents recorded in $0.2 \mathrm{~mm}$ calcium represents $47.8 \pm 4.1 \%$ of the mean current measured in $2 \mathrm{~mm}$ calcium, whereas the mean current recorded in $20 \mathrm{~mm}$ calcium represents only $35.8 \pm 4.3 \%$ ( 5 cells). High extracellular calcium is a negative modulator of the human $\alpha 4 \beta 2 \mathrm{nAChR}(C)$. When external $\mathrm{Ca}^{2+}$ jumped to 10 and $20 \mathrm{~mm}$ during the ACh pulse, a fast and fully reversible block of the ACh-evoked current was observed, indicating the concentration dependence of the calcium effect $(n=3)$. A high extracellular calcium concentration decreases the single-channel conductance of the human $\alpha 4 \beta 2 \mathrm{nAChR}(D-F)$. Holding potentials of $-100,-80,-60$, $-40,-20$, and $20 \mathrm{mV}$ were changed at $5 \mathrm{sec}$ intervals. One second after the voltage setting, the patch was challenged by $3 \mu \mathrm{M}$ ACh for $200 \mathrm{msec}$. Such protocol was applied alternately in 20 and $2 \mathrm{mM} \mathrm{CaCl}_{2}$ (3 patches). $D$ presents two traces of the records performed successively in 20 and $2 \mathrm{~mm} \mathrm{CaCl} 2$. Even in the presence of the fast run-down mechanism, the total amount of current is much larger in 2 than in $20 \mathrm{~mm} \mathrm{Ca}^{2+}$ (at all membrane potentials tested). The horizontal bar represents the $3 \mu \mathrm{M}$ ACh pulse. Reduction of the single-channel conductance induced by high extracellular calcium is illustrated in $E$. Patch was held throughout the experiment at $-100 \mathrm{mV}$. Single-channel amplitudes (corresponding to the main conductance observed) were plotted as a function of the holding potential $(F)$ and fit with the equation $i=\gamma \times\left(E-E_{\mathrm{r}}\right)$, where $i$ is the current, $\gamma$ is the conductance, $E$ is the holding voltage, and $E_{\mathrm{r}}$ is the current reversal potential. In $20 \mathrm{mM} \mathrm{Ca}^{2+}$, the main conductance decreases from 46 to $28 \mathrm{pS}$ (see text).
} 
azole (ABT-418): a novel cholinergic ligand with cognition-enhancing and anxiolytic activities: I. In vitro characterization. J Pharmacol Exp Ther 270:310-318.

Arneric SP, Sullivan JP, Decker MW, Brioni JD, Bannon AW, Briggs CA, Donnelly-Roberts D, Radek RJ, Marsh KC, Kyncl J, Williams M, Buccafusco JJ (1995) Potential treatment of Alzheimer disease using cholinergic channel activators (ChCAs) with cognitive enhancement, anxiolyticlike, and cytoprotective properties. Alzheimer Dis Assoc Disord 9:50-61.

Aubert I, Araujo DM, Cécyre D, Robitaille Y, Gauthier S, Quirion R (1992) Comparative alterations of nicotinic and muscarinic binding sites in Alzheimer's and Parkinson's diseases. J Neurochem 58:529-541.

Ballivet M, Nef P, Couturier S, Rungger D, Bader CR, Bertrand D, Cooper E (1988) Electrophysiology of a chick neuronal nicotinic acetylcholine receptor expressed in Xenopus oocytes after cDNA injection. Neuron 1:847-852.

Baron JA (1986) Cigarette smoking and Parkinson's disease. Neurology 36:1490-1496.

Beck C, Moulard B, Steinlein O, Guipponi M, Vallee L, Montpied P, Baldy-Moulinier M, Malafosse A (1994) A nonsense mutation in the 4 subunit of the nicotinic acetylcholine receptor $(\alpha 4)$ cosegregates with $20 \mathrm{q}$-linked benign familial neonatal convulsions (EBN1). Neurobiol Dis 1:95-99.

Bertrand D, Bader CR (1986) DATAC: A multipurpose biological data analysis program based on mathematical interpreter. Int $\mathbf{J}$ Biomed Comput 18:193-202.

Bertrand D, Changeux JP (1995) Nicotinic receptor: an allosteric protein specialized for intercellular communication. Semin Neurosci 7:75-90.

Bertrand D, Ballivet M, Rungger D (1990) Activation and blocking of neuronal nicotinic acetylcholine receptor reconstituted in Xenopus oocytes. Proc Natl Acad Sci USA 87:1993-1997.

Bertrand D, Galzi JL, Devillers-Thiéry A, Bertrand S, Changeux JP (1993) Mutations at two distinct sites within the channel domain M2 alter calcium permeability of neuronal $\alpha 7$ nicotinic receptor. Proc Natl Acad Sci USA 90:6971-6975.

Bertrand D, Buisson B, Krause RM, Hu H-Y, Bertrand S (1997) Electrophysiology: a method to investigate the functional properties of ligand-gated channels. J Recept Signal Transduction Res, in press.

Bonfante-Cabarcas R, Swanson KL, Alkondon M, Albuquerque EX (1996) Diversity of nicotinic acetylcholine receptors in rat hippocampal neurons. IV. Regulation by external $\mathrm{Ca}++$ of $\alpha$-bungarotoxin-sensitive receptor function and of rectification induced by internal $\mathrm{Mg}++$. J Pharmacol Exp Ther 277:432-444.

Bowie D, Mayer ML (1995) Inward rectification of both AMPA and kainate subtype glutamate receptors generated by polyamine-mediated ion channel block. Neuron 15:453-462.

Cachelin AB, Rust G (1995) $\beta$-subunits co-determine the sensitivity of rat neuronal nicotinic receptors to antagonists. Pflügers Arch 429:449-451.

Charnet P, Labarca C, Cohen BN, Davidson N, Lester HA, Pilar G (1992) Pharmacological and kinetic properties of $\alpha 4 \beta 2$ neuronal nicotinic acetylcholine receptors expressed in Xenopus oocytes. J Physiol (Lond) 450:375-394.

Chavez-Noriega LE, Crona J, Tran C, Elliott K, Corey-Naeve J, Urrutia A, Johnson EC (1995) Characterization of recombinant human neuronal nicotinic ACh receptors expressed in HEK 293 cells and Xenopus oocyte. Soc Neurosci Abstr 36.5.

Clarke PBS, Schwartz RD, Paul SM, Pert CB, Pert A (1985) Nicotinic binding in rat brain: autoradiographic comparison of $\left[{ }^{3} \mathrm{H}\right]$ acetylcholine, $\left[{ }^{3} \mathrm{H}\right]$ nicotine, and $\left[{ }^{125} \mathrm{I}\right]$-alpha-bungarotoxin. J Neurosci 5:1307-1315.

Conroy WG, Vernallis AB, Berg DK (1992) The $\alpha 5$ gene product assembles with multiple acetylcholine receptor subunits to form distinctive receptor subtypes in brain. Neuron 9:679-691.

Cooper E, Couturier S, Ballivet M (1991) Pentameric structure and subunit stoichiometry of a neuronal acetylcholine receptor. Nature 350:235-238.

Corringer P-J, Galzi J-L, Eiselé J-L, Bertrand S, Changeux J-P, Bertrand D (1995) Identification of a new component of the agonist binding site of the nicotinic $\alpha 7$ homooligomeric receptor. J Biol Chem 270:11749-11752.

Corriveau RA, Romano SJ, Conroy WG, Oliva L, Berg DK (1995) Expression of neuronal acetylcholine receptor genes in vertebrate skeletal muscle during development. J Neurosci 15:1372-1383.

De Fiebre CM, Meyer EM, Henry JC, Muraskin SI, Kem WR, Papke RL (1995) Characterization of a series of anabaseine-derived compounds reveals that the 3 -(4)-dimethylaminocinnamylidine derivative is a selective agonist at neuronal nicotinic $\alpha 7 /{ }^{125} \mathrm{I}$ - $\alpha$-bungarotoxin receptor subtypes. Mol Pharmacol 47:164-171.
Decker ER, Dani JA (1990) Calcium permeability of the nicotinic acetylcholine receptor: the single channel influx is significant. J Neurosci 10:3413-3420.

Decker MW, Curzon P, Brioni JD, Arneric SP (1994a) Effects of ABT418, a novel cholinergic channel ligand, on place learning in septallesioned rats. Eur J Pharmacol 261:217-222.

Decker MW, Brioni JD, Sullivan JP, Buckley MJ, Radek RJ, Raszkiewicz JL, Kang CH, Kim DJ, Giardina WJ, Wasicak JT, Garvey DS, Arneric SP (1994b) (S)-3-methyl-5-(1-methyl-2-pyrrolidinyl)isoxazole (ABT-418): a novel cholinergic ligand with cognition-enhancing and anxiolytic activities: II. In vivo characterization. J Pharmacol Exp Ther 270:319-328.

Deutch AY, Holliday J, Roth RH, Chun LLY, Hawrot E (1987) Immunohistochemical localization of a neuronal nicotinic acetylcholine receptor in mammalian brain. Proc Natl Acad Sci USA 84:8697-8701.

Doucette-Stamm L, Monteggia LM, Donnelly-Roberts D, Wang MT, Lee J, Tian J, Giordano T (1993) Cloning and sequence of the human $\alpha 7$ nicotinic acetylcholine receptor. Drug Dev Res 30:252-256.

Drasdo A, Caulfield M, Bertrand D, Bertrand S, Wonnacott S (1992) Methyllycaconitine: a novel nicotinic antagonist. Mol Cell Neurosci 3:237-243

Duvoisin RM, Deneris ES, Patrick J, Heinemann S (1989) The functional diversity of the neuronal nicotinic acetylcholine receptors is increased by a novel subunit: beta4. Neuron 3:487-496.

Eiselé JL, Bertrand S, Galzi JL, Devillers-Thiéry A, Changeux JP, Bertrand D (1993) Chimaeric nicotinic-serotoninergic receptor combines distinct ligand binding and channel specificities. Nature 366:479-483.

Falker B, Brandle U, Glowatzki E, Weidemann S, Zenner HP, Ruppersberg JP (1995) Strong voltage-dependent inward rectification of inward rectifier $\mathrm{K}^{+}$channels is caused by intracellular spermine. Cell 80:149-154.

Ficker E, Taglialatela M, Wible BA, Henley CM, Brown AM (1994) Spermine and spermidine as gating molecules for inward rectifier $\mathrm{K}^{+}$ channels. Science 266:1068-1072.

Flores CM, Rogers SW, Pabreza LA, Wolfe BB, Kellar KJ (1992) A subtype of nicotinic cholinergic receptor in rat brain is composed of alpha 4 and beta 2 subunits and is up-regulated by chronic nicotine treatment. Mol Pharmacol 41:31-37.

Forster I, Bertrand D (1995) Inward rectification of neuronal nicotinic acetylcholine receptors investigated by using the homomeric $\alpha 7$ receptor. Proc R Soc Lond [B] 260:139-148.

Galzi JL, Changeux JP (1995) Neuronal nicotinic receptors: molecular organization and regulations. Neuropharmacology 34:563-582.

Goff DS, Henderson DC, Amico E (1992) Cigarette smoking in schizophrenia: relationship to psychopathology and medication side effects. Am J Psychiatry 149:1189-1194.

Gopalakrishnan M, Buisson B, Touma E, Giordano T, Campbell JE, Hu IC, Donnelly-Roberts D, Arneric SP, Bertrand D, Sullivan JP (1995) Stable expression and pharmacological properties of the human $\alpha 7$ nicotinic acetylcholine receptor. Eur J Pharmacol Mol Pharmacol Sect 290:237-246.

Gopalakrishnan M, Monteggia LM, Anderson DJ, Molinari EJ, PiattoniKaplan M, Donnelly-Roberts D, Arneric SP, Sullivan JP (1996) Stable expression, pharmacological properties and regulation of the human neuronal nicotinic acetylcholine $\alpha 4 \beta 2$ receptor. J Pharmacol Exp Ther 276:289-297.

Hamill OP, Marty A, Neher E, Sakmann B, Sigworth FJ (1981) Improved patch-clamp techniques for high-resolution current recordings from cells and cell-free patches. Pflügers Arch 391:85-100.

Harvey SC, Luetje CW (1996) Determinants of competitive antagonist sensitivity on neuronal nicotinic receptor $\beta$ subunits. J Neurosci 15:3798-3806.

Hunter BE, de Fiebre CM, Papke RL, Kem WR, Meyer EM (1994) A novel nicotinic agonist facilitates induction of long-term potentiation in the rat hippocampus. Neurosci Lett 168:130-134.

Hussy N, Ballivet M, Bertrand D (1994) Agonist and antagonist effects of nicotine on chick neuronal nicotinic receptors are defined by alpha and beta subunits. J Neurophysiol 72:1317-1326.

Ifune CK, Steinbach JH (1991) Voltage-dependent block by magnesium of neuronal nicotinic acetylcholine receptor channels in rat phaeochromocytoma cells. J Physiol (Lond) 443:683-701.

Ifune CK, Steinbach JH (1992) Inward rectification of acetylcholineelicited currents in rat phaeochromocytoma cells. J Physiol (Lond) 457:143-165. 
Ifune CK, Steinbach JH (1993) Modulation of acetylcholine-elicited currents in clonal rat phaeochromocytoma (PC12) cells by internal polyphosphates. J Physiol (Lond) 463:431-447.

Imoto K, Busch C, Sakmann B, Mishina M, Konno T, Nakai T, Bujo H, Mori Y, Fukuda K, Numa S (1988) Rings of negatively charged amino acids determine acetylcholine receptor channel conductance. Nature 335:645-648.

Janson AM, Hedlund PB, Fuxe K, von Euler G (1994) Chronic nicotine treatment counteracts dopamine $\mathrm{D} 2$ receptor upregulation induced by a partial meso-diencephalic hemitransection in the rat. Brain Res 655:25-32.

Jones GMM, Sahakian BJ, Levy R, Warburton DM, Gray JA (1992) Effects of acute subcutaneous nicotine on attention, information processing and short-term memory in Alzheimer's disease. Psychopharmacology 108:448-451.

Karlin A, Akabas MH (1995) Toward a structural basis for the function of nicotinic acetylcholine receptors and their cousins. Neuron 15:1231-1244.

Kellar KJ, Gibbin BA, Lumpkin MD (1989) Regulation of brain nicotinic cholinergic recognition sites and prolactin releases by nicotine. Prog Brain Res 79:209-216.

Le Novère N, Changeux JP (1995) Molecular evolution of the nicotinic acetylcholine receptor: an example of multigene family in excitable cells. J Mol Evol 40:155-172.

Léna C, Changeux JP (1993) Allosteric modulations of the nicotinic acetylcholine receptor. Trends Neurosci 16:181-186.

Levin ED (1992) Nicotinic systems and cognitive function. Psychopharmacology 108:417-431.

Lindstrom J (1995) Nicotinic acetylcholine receptors. In: Ligand- and voltage-gated ion channels (North RA, ed), pp 153-175. Boca Raton, FL: CRC.

Lindstrom J (1996) Neuronal nicotinic acetylcholine receptors. In: Ion channels, Vol 4 (Narahashi T, ed), pp 377-450. New York: Plenum.

Lopatin AN, Makhina EN, Nichols CG (1994) Potassium channel block by cytoplasmic polyamines as the mechanism of intrinsic rectification. Nature 372:366-369.

Luetje CW, Wada K, Rogers S, Abramson SN, Tsuji K, Heinemann S, Patrick J (1990) Neurotoxins distinguish between different neuronal nicotinic acetylcholine receptor subunit combinations. J Neurochem 55:632-640.

Lukas RJ (1995) Diversity and patterns of regulation of nicotinic receptor subtypes. Ann NY Acad Sci 757:153-168.

McGehee DS, Role LW (1995) Physiological diversity of nicotinic acetylcholine receptors expressed by vertebrate neurons. Annu Rev Physiol 57:521-546.

Marks MJ, Pauly JR, Gross SD, Deneris ES, Hermans-Borgmeyer IH, Heinemann SF, Collins AC (1992) Nicotine binding and nicotinic receptor subunit RNA after chronic nicotine treatment. J Neurosci 12:2765-2784.

Mathie A, Colquhoun D, Cull-Candy SG (1990) Rectification of currents activated by nicotinic acetylcholine receptors in rat sympathetic ganglion neurons. J Physiol (Lond) 427:625-655.

Monteggia LM, Gopalakrishnan M, Touma E, Idler KB, Nash N, Arneric SP, Sullivan JP, Giordano T (1995) Cloning and transient expression of genes encoding the human alpha 4 and beta 2 neuronal nicotinic acetylcholine receptor (nAChR) subunits. Gene: 155:189-193.

Mulle C, Changeux JP (1990) A novel type of nicotinic receptor in the rat central nervous system characterized by patch-clamp techniques. J Neurosci 10:169-175.

Mulle C, Vidal C, Benoit P, Changeux JP (1991) Existence of different subtypes of nicotinic acetylcholine receptors in the rat habenulointerpeduncular system. J Neurosci 11:2588-2597.

Mulle C, Léna C, Changeux JP (1992) Potentiation of nicotinic receptor response by external calcium in rat central neurons. Neuron 8:937-945.

Neuhaus R, Cachelin AB (1990) Changes in the conductance of the neuronal nicotinic acetylcholine receptor channel induced by magnesium. Proc R Soc Lond [B] 241:78-84.

Palma E, Bertrand S, Binzoni T, Bertrand D (1996) Homomeric neuronal nicotinic $\alpha 7$ receptor presents five putative high affinity binding sites for the toxin MLA. J Physiol (Lond) 491.1:151-161.

Papke RL, Boulter J, Patrick J, Heinemann S (1989) Single-channel currents of rat neuronal nicotinic acetylcholine receptors expressed in Xenopus oocyte. Neuron 3:589-596.

Peng X, Katz M, Gerzanich V, Anand R, Lindstrom J (1994) Human alpha 7 acetylcholine receptor: cloning of the alpha 7 subunit from the
SH-SY5Y cell line and determination of pharmacological properties of native receptors and functional alpha 7 homomers expressed in Xenopus oocytes. Mol Pharmacol 45:546-554.

Pereira EFR, Alkondon M, Reinhardt S, Maelicke A, Peng X, Linstrom J, Whiting P, Albuquerque EX (1994) Physostigmine and galanthamine: probes for a novel binding site on the $\alpha 4 \beta 2$ subtype of neuronal nicotinic acetylcholine receptors stably expressed in fibroblast cells. J Pharmacol Exp Ther 270:768-778.

Perry EK, Morris CM, Court JA, Cheng A, Faibairn AF, McKeith IG, Irving D, Brown A, Perry RH (1995) Alteration in nicotine binding sites in Parkinson's disease, Lewy Body Dementia and Alzheimer's disease: possible index of early neuropathology. Neuroscience 64:385-395.

Picciotto MR, Zoli M, Lena C, Bessis A, Lallemand Y, LeNovere N, Vincent P, Pich EM, Brulet P, Changeux JP (1995) Abnormal avoidance learning in mice lacking functional high-affinity nicotine receptor in the brain. Nature 374:65-67.

Puchacz E, Buisson B, Bertrand D, Lukas RJ (1994) Functional expression of nicotinic acetylcholine receptors containing rat alpha 7 subunits in human SH-SY5Y neuroblastoma cells. FEBS Lett 354:155-159.

Sanderson EM, Drasdo AL, McRea K, Wonnacot S (1993) Upregulation of nicotinic receptors following continuous infusion of nicotine is brain region-region specific. Brain Res 617:349-352.

Sands SB, Barish ME (1992) Neuronal nicotinic receptor currents in Phaeochromocytoma (PC12) cells: dual mechanisms of rectification. J Physiol (Lond) 447:467-487.

Schoepfer R, Whiting P, Esch F, Blacher R, Shimasaki S, Lindstrom J (1988) cDNA clones coding for the structural subunit of a chicken brain nicotinic acetylcholine receptor. Neuron 1:241-248.

Schubert S, Lacconne F, Lefterov I, Nacheva M, Hansman I (1994) Towards positional cloning of the locus for benign neonatal epilepsy (EBN1) on chromosome 20. Am J Hum Genet 55[Suppl. 3]:A270, Abstr 1579.

Silver AA, Sandberg PR (1993) Transdermal nicotine patch and potentiation of haloperidol in Tourette's Syndrome. Lancet 342:182.

Steinlein OK, Mulley JC, Propping P, Wallace RH, Philipps HA, Sutherland GR, Scheffer IE, Berkovic SF (1995) A missense mutation in the neuronal nicotinic acetylcholine receptor $\alpha 4$ subunit is associated with autosomal dominant nocturnal frontal lobe epilepsy. Nature Genet 11:201-203.

Sullivan JP, Gopalakrishnan M, Monteggia LM, Anderson DJ, Buisson B, Bertrand D, Arneric SP (1995) Pharmacological properties of the human $\alpha 4 \beta 2$ nicotinic acetylcholine receptor (nAChR) stably expressed in a mammalian cell line. Soc Neurosci Abstr 36.6.

Swanson LW, Simmons DM, Whiting PJ, Lindstrom J (1987) Immunohistochemical localization of neuronal nicotinic receptors in the rodent central nervous system. J Neurosci 7:3334-3342.

Vernino S, Amador M, Luetje CW, Patrick J, Dani JA (1992) Calcium modulation and high calcium permeability of neuronal nicotinic acetylcholine receptors. Neuron 8:127-134.

Wada E, Wada K, Boulter J, Deneris E, Heinemann S, Patrick J, Swanson LW (1989) Distribution of alpha2, alpha3, alpha4, and beta2 neuronal nicotinic receptor subunit $\mathrm{mRNAs}$ in the central nervous system: a hybridization histochemical study in the rat. J Comp Neurol 284:314-335.

Warburton DM (1992) Nicotine as a cognitive enhancer. Prog Neuropsychopharmacol Biol Psychiatry 16:181-191.

Wevers A, Jeske A, Lobron C, Birtsch C, Heinemann S, Maelicke A, Schroder R, Schroder H (1994) Cellular distribution of nicotinic acetylcholine receptor subunit mRNAs in the human cerebral cortex as revealed by non-isotopic in situ hybridization. Brain Res Mol Brain Res 25:122-128.

Whitehouse P, Martino A, Antuono P, Kellar K (1986) Nicotinic acetylcholine binding sites in Alzheimer's disease. Brain Res 371:146-151.

Whiting P, Esch F, Shimasaki S, Lindstrom J (1987) Neuronal nicotinic acetylcholine receptor $\beta$-subunit is coded for by the cDNA clone $\alpha 4$. FEBS Lett. 219:459-463.

Whiting P, Schoepfer R, Lindstrom J, Priestey T (1991) Structural and pharmacological characterization of the major brain nicotinic acetylcholine receptor subtype stably expressed in mouse fibroblasts. Mol Pharmacol 40:463-472.

Wong ET, Holstad SG, Mennerick SJ, Hong SE, Zorumski CF, Isenberg KE (1995) Pharmacological and physiological properties of a putative ganglionic nicotinic receptor, $\alpha 3 \beta 4$, expressed in transfected eucaryotic cells. Mol Brain Res 28:101-109.

Wonnacott S, Albuquerque EX, Bertrand D (1993) Methyllycaconitine: a new probe that discriminates between nicotinic receptor subclasses. Methods Neurosci 12:263-275. 